\title{
NOTÍCIA DE LA SEU I CAPÍTOL DE TORTOSA A L'ARXIU DE LA CORONA D'ARAGÓ (SEGLES XIV-XV)
}

JOSEP ALANYÀ I ROIG, PVRE. I.B. Infanta Isabel d'Aragó. Barcelona

\author{
SUMARI
}

1. Les obres i fàbrica de la seu.- 2. El capítol catedralici.

En memòria i homenatge de la ben estimada Regina Sáinz de la Maza, prematurament arrabassada de la nostra companyia terrenal el 13 d'agost de 1997, tinc el goig de participar en la rica miscel-lània que la Institució Milà i Fontanals dedica a qui fou molts anys, fins a la mort, la seva eficaç vicedirectora. I ho faig, ara que la meva diòcesi de Tortosa celebra solemnement els 400 anys de la seva consagració pel bisbe Gaspar Punter, amb la publicació de les dades, gairebé totes elles inèdites, descobertes dia rera dia en els fons de Cancelleria i de Reial Patrimoni de l'Arxiu Reial de Barcelona. D'aquestes dades, moltes han estat trobades en presència de l'amiga Regina; algunes d'elles, brindades amb generositat amorosa, són fruit de la seva recerca; i gairebé totes, les hem celebrat $\mathrm{i}$ comentat ella i jo, amb la satisfacció pròpia dels investigadors, a la taula de treball que compartíem i en els itineraris d'anada i tornada de l'arxiu que fèiem plegats.

L'estimada Regina ens ha precedit en el camí cert de la mort. Per als qui hem estat els seus amics és un consol mutu, molt humà, de poder 
oferir-li en honor de la seva memòria allò que la Regina més estimava en el món acadèmic i científic: la recerca i la publicació dels seus resultats.

\section{LES OBRES I FABRICA DE LA SEU}

1. La seu gòtica de Tortosa ha estat objecte de nombroses publicacions i d'alguns estudis que mereixen tenir-se en compte. Tanmateix, com fa constar la historiadora Victòria Almuni, estudiosa de l'obra de la seu tortosina, en la majoria dels casos la bibliografia publicada pateix d'una manca de rigor científic "tant pel que fa a la metodologia com a les hipòtesis i interpretacions a què s'arriba", fet que no afavoreix les tasques de recerca. Almuni lamenta així mateix que siguin ben escasses les notícies extretes directament de la documentació arxivística i poques, per tant, les interpretacions raonades fundades en la comparació edifici-informació publicada ${ }^{1}$. Troba a faltar, doncs, estudis basats en la recerca directa de les fonts documentals que guarden arxius com el Capitular de Tortosa, on hi ha onze sèries documentals del capítol de la seu des de l'any 1148 , objecte de recerca per part de la historiadora, i altres arxius que ella esmenta explícitament com són l'Arxiu Municipal de Tortosa, el Capitular de la Seu de Barcelona i l'Arxiu de la Corona d'Aragó. I pel que fa a la bibliografia, en dóna raó completa i en fa una anàlisi crítica.

En aquest article dedicat a la seu i capítol de Tortosa confio de poder aportar al món científic dades prou abundoses i interessants procedents de la Cancelleria Reial, que esdevindran confirmació i complement de les que hagin guardat fins avui els arxius, sobretot l'Arxiu Capitular de Tortosa.

La construcció de l'edifici de la seu actual de Tortosa va començar a preparar-se de manera decidida en temps del bisbe Berenguer de Prats, el bon pastor que, pagant la pena de 9 lliures i 4 sous, va salvar de la forca la vida d'un noiet de dotze anys, insolvent, que havia estat condemnat pels paers de la ciutat a satisfer aquesta quantitat en el termini de deu dies pel furt d'unes abelles ${ }^{2}$. Berenguer de Prats i el capítol van fixar el terreny que, inclòs el de la seu romànica, havia d'ocupar el nou temple; i el bisbe mateix, donant exemple del que calia fer, va donar deixes importants per a l'obra

\footnotetext{
'Victòria Almuni Balada, L'obra de la Seu de Tortosa (1345-1441), p. 23.

${ }^{2}$ ACA, Cancelleria, reg. 226, fol. $140 \mathrm{r}$.
} 
ordenant que hi fossin destinats també els diners i les rendes dels beneficis vacants de la ciutat i de la diòcesi.

L'any 1345 , hi havia ja un projecte, el del mestre d'obres Antoni Guarc, que no es va realitzar. Els cinc anys de l'episcopat d'Arnau de Lordat, bisbe elegit pel papa Benet XII en virtut de la reserva papal, invalidant l'elecció del capítol a favor del canonge Guillem de Sentmenat, els fons per a la fàbrica de la seu van crèixer molt. L'any 1345, era contractat com a mestre major de l'obra de la seu Bernat d'Alguaire, qui, el mes d'agost, a Bítem, va presentar el projecte al bisbe i al capítol fent-ne una mostra a escala natural ${ }^{3}$. I el 21 de maig de 1347, el bisbe Bernat Oliver, que venia de Barcelona, on la construcció de la catedral era en plena activitat, posava la primera pedra.

Segons Almuni, les obres començaren a la capella central del presbiteri i, l'any 1351, ja s'havia construït l'altar major, consagrant-se aleshores l'absis, ja acabat ${ }^{4}$. La nova catedral, tot $\mathrm{i}$ algunes interrupcions en l'obra, anava aixecant els seus murs als peus de l'elevació natural i castell de la Suda. I és amb aquest progrés de les obres, urbanitzador de la zona, i amb la seguretat de la fortalesa que relaciono la següent ordre reial enviada a les autoritats tortosines. El 13 d'octubre de 1363, de Lleida estant, Pere el Cerimoniós manava al mostassaf de Tortosa, Ramon Pinyol, i a l'obrer del castell, Pere Çacosta, "ques tanquen totes les cavernes que són entorn les faldes del castell de la nostra ciutat de Tortosa" perquè "per relació del feel de la cambra nostra, Arnau Torrelles, havem entès que de necessitat és obs ${ }^{5}$. Poc abans, el rei havia entrat a Tortosa: "huy que és dicmenge a XXIII de juliol en ora de vespres entram en la ciutat de Tortosa... E de continent en la nostra entrada haguem possessió de la ciutat e del castell de Tortosa" ${ }^{\prime \prime}$. Des del castell havia pogut contemplar les obres de la nova seu que s'aixecava al peu de la fortalesa. Fou en aquesta estada a la ciutat quan el rei Pere, el 25 de juliol, va escriure a Arnau Torrelles perquè recobrés del bisbe Jaume d'Aragó el romanç de Godofred IV de Boulogne, conegut com Godofred de Bouillon: "Item, recobrats del bisbe de Tortosa un romanç que

\footnotetext{
${ }^{3}$ ALMUNI, ob. cit., pp. 59-61; pp. 290-291.

${ }^{4}$ ALMUNi, ob. cit., p. 33.

${ }^{5} \mathrm{ACA}$, Cancelleria, reg. 1194, fol. 4 v.

${ }^{6} \mathrm{ACA}$, Cancelleria, reg. 1190, fols. 379 v. $-380 \mathrm{r}$.
} 
fon del Infant en Ferrando al qual dien Romanç de Gotfre de Bello, lo qual lo dit bisbe havia donat a Gomeç Carriello sens licència e volentat nostra"?.

L'obra de la seu anava progressant i, segons Almuni, entre els anys 1376 i 1378 l'activitat constructora se centrava al sector de la capella de Sant Pere i l'escala de cargol contigua. Són de l'any 1377 aquestes dues anotacions del Llibre de l'Obra: "... a'n Curça qui-y fo II jorns per fer mollos al caragol e del pilar de la capella de Sent P..."; "...hi fo en Curça per fer lo bastiment de la capella de Sent P..." ${ }^{8}$. Però la documentació que he trobat a l'Arxiu de la Corona d'Aragó ens demostra que l'activitat centrada en aquest sector cal perllongar-la fins a ben entrat l'any 1383. En efecte, en data del 22 d'abril de l'any esmentat, Pere III, que era a Tortosa i havia visitat les obres de la seu, assabentat que el mestre Joan de Mayni volia partir de la ciutat abans de ser acabada la capella de sant Pere, l'obliga a quedar-s'hi, a acabar l'obra sota pena de 100 morabatins d'or i a quedar a disposició dels procuradors de l'obra de la seu, sense el permís dels quals no podria en endavant absentar-se de l'obra ni de la ciutat'

Aquest document que mostra la intervenció reial s'explica perquè era freqüent que un mestre d'obra contractés alhora la direcció de diverses construccions en una mateixa ciutat i fins i tot en diferents llocs geogràfics, per la qual cosa s'havia d'absentar d'una obra per fer la visura de les altres. Aquest sentit sembla que té l'anotament del Llibre d'Obra publicat per Victòria Almuni: "Item a mestre Johan, qui y vench per ço que mostràs lo dictat de la hobra e com mes en nostro poder la carta ab que s-en tornàs... V sous"10. El "dictat de la hobra" era el projecte o mostra i "la carta" que el mestre deixà en mans dels procuradors de la construcció de la catedral era el plànol.

El document de Cancelleria Reial, que vaig descobrir l'any 1994, ve a resoldre un enigma secular que ha planat sobre la direcció de les obres de la seu de Tortosa i que encara és viu al llibre de la Victòria Almuni, publicat l'any 1991. O'Callaghan, Matamoros i els altres autors que han escrit sobre la catedral tortosina ignoren que, entre els mestres d'obra, hi hagué Joan de Mayni. Victòria Almuni diu que entre l'any 1386 i el 1389 "és mestre un tal

\footnotetext{
${ }^{7} \mathrm{ACA}$, Cancelleria, reg. 1190 , fol. 435 r.

${ }^{8}$ ALMUNI, ob. cit., pp. 64 i 87.

${ }^{9} \mathrm{ACA}$, Cancelleria, reg. 832 , fols. 177 v.-178 r. Apèndix documental, núm. 4.

${ }^{10}$ AlmuNi, ob. cit., p. 64.
} 
Johan, que consta a l'obra totes les setmanes excepte quan viatja a la pedrera". I en la nota 22 afirma que "concorda amb la relació cronològica que dels mestres ens dóna J. Matamoros, segons el qual Pascasi de Xulbe i el seu fill Joan treballen com a mestres de la seu entre 1301 i 1428" . Aquest mestre apareix novament al Llibre d'Obra núm. 7, en anotament del mes d'octubre: "...mestre Johan que no-y fo, ans fo a la hobra del mur de la ciutat...", la qual cosa fa creure amb raó a Almuni que "aquest costum no devia ser estrany en ell, ja que l'any 1393 consta que obra alguns dies en el convent dels frares menors"12. Això confirma el que he dit abans, que el mestre s'absentava sovint de l'obra de la seu perquè havia de dirigir o visurar altres obres a la mateixa ciutat i terme, com l'obra de les muralles, la construcció de l'esglesiola de La Petja, segons que m'ha comunicat personalment Victòria Almuni, construcció disposta l'any 1378 per Guerau de Montbrú, ardiaca de Culla, o altres obres que ignorem de llocs distants de la ciutat. En el cas de La Petja era el mateix procurador de les obres de la seu, l'ardiaca de Culla, qui, encarregant-li una nova construcció, feia absentar el mestre de l'obra de la seu.

En el llibre publicat l'any 1991, Victòria Almuni ignorava la identitat del mestre Joan de Mayni: "Dalguaire sembla que treballà a la fàbrica de la seu tortosina per espai d'uns 20 anys. No compartim, però, la idea de J. Matamoros segons la qual hauria estat substituït per Andreu Julià, ja que consta que l'any 1375-76 era mestre un tal "Joan" (llibre d'obres, 3, fol. 28 v. $)^{13}$. Com l'havien ignorat els historiadors i estudiosos de la seu anteriors a ella.

Aquesta ignorància venia de l'absència de documentació a l'Arxiu Capitular, una part de la qual s'ha trobat en aparèixer alguns llibres d'obra de la seu a l'Arxiu Diocesà. La troballa ha permès a Almuni d'identificar el "mestre Johan" amb Joan de Mayni, com jo l'havia trobat ja documentat a l'Arxiu de la Corona d'Aragó, si bé el seu nom, segons comunicació d'Almuni, apareix en les notes capitulars com "Joan de Manyi", amb una petita variació, per metàtesi, en el cognom.

Fins a aquesta descoberta documental -i així ho pensava també Matamoros- hom havia identificat el "mestre Johan" (Joan de Mayni) amb

\footnotetext{
"Almuni, ob. cit., pp. 65 i 103.

${ }^{12}$ AlMUNI, ob. cit., p. 67.

${ }^{13}$ ALMUNi, ob. cit., p. 115
} 
"Joan de Exulbi": "El 1386, no obstant, el mestre de la seu és esmentat de nou amb el nom de Joan, amb continuïtat en els llibres fins el 1422, quan per primera vegada apareix especificat el nom de "Joan de Exulbi" (ll. o. 9, f. 18 r.-22 r. i $26 \mathrm{v}$ ). És possible que els llibres es referissin a ell els anys anteriors, en què no trobem especificat cognom ja que el canonge Matamoros el situa com a mestre, junt amb el seu pare Pascasi, entre 1381 i 1428. (...) la notícia del mestratge de Joan de Xulbi, o Exulbe, continua en els llibres fins el 1435-36, període excessivament llarg per a una mateixa persona"14. Amb raó, doncs, insinuava Almuni que el "mestre Joan" del 1386 no podia ser la mateixa persona que el mestre Joan de Exulbi. Ara ja ho sabem gràcies al coneixement de l'existència de mestre Joan de Mayni. Això vol dir que cal corregir la tesi del canonge Matamoros segons la qual "Joan de Exulbi" hauria estat ja mestre de l'obra de la seu l'any 1381, quan la documentació de l'Arxiu de la Corona d'Aragó i la trobada a l'Arxiu Diocesà demostren que, l'any 1383, encara era mestre de l'obra Joan de Mayni.

2. Del període comprès entre els anys 1401 i 1409, corresponent als comptes de Bartomeu Doménech, batlle de Tortosa, és la notícia relativa a l'escala de cargol de la capella de Sant Pere:

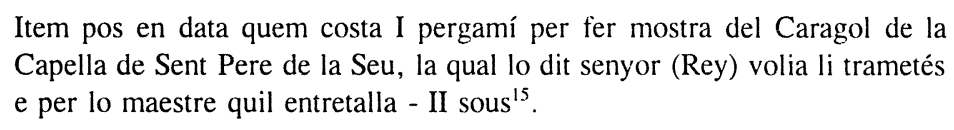

L'existència d'un pergamí per fer la mostra de l'escala de cargol és suficient per demostrar que el mestre de la seu havia de disposar de plànols, croquis i esquemes parcials i totals de l'obra, de dimensions reduïdes i fets a escala, encara que no tinguem altra notícia de croquis o plànols que aquesta i la de "lo dictat de la hobra" i "la carta", això és, el projecte i el plànol de l'obra, que mestre Joan de Mayni lliurà a mans dels procuradors de l'obra de la seu.

Almuni creu que la capella de Sant Pere ja era acabada l'any 1386-87, quan s'encarregà a Domènec Valls la pintura de la finestra ${ }^{16}$. L'escala de cargol devia ser també acabada en aquestes dates; i la mostra que

\footnotetext{
${ }^{14}$ Ibidem.

${ }^{15}$ ACA, Reial Patrimoni, Mestre racional, 1625/3, fol. 19 r.

${ }^{16}$ Almuni, ob. cit., pp. 65-87.
} 
se'n trauria en un pergamí per al rei Martí podria anar destinada a una altra construcció.

3. La construcció del retaule major de la seu havia estat acordada l'any 1351 implicant-se en ella la universitat tortosina mitjançant el nomenament de síndics encarregats d'aconseguir mestres escultors i pintors $i$, un cop trobats i escollits, de contractar amb ells els preus de l'obra i, òbviament, els terminis de pagament i lliurament. Així consta en una nota del notari Sunyol, citada per José i Pitarch:

Sindicos ad concordandum super fabricam Altaris Maioris. 1351-1352 -

Kls. Septembris Anno Domini M CCC LI... et ordinarunt certos et speciales Sindicos, Economos et Procuratores... ad conducendum Magistrum et Magistros qui necessarii fuerint ad fabricandum Tabernaculum faciendum in ornamentum Altaris Maioris Beatae Virginis Mariae dicte ecclesiae Dertusen. Et ad conveniendum de pretio vel pretiis cum eiusdem magistro vel magistris... ${ }^{17}$

D'aquest retaule no sabem res més. El cert és que no seria instal·lat a l'altar major de la nova catedral fins que almenys fos ja acabada de construir la zona de la girola i del presbiteri. I, per tant, tots els indicis apunten a un encàrrec molt prematur de l'obra del retaule per part dels representants municipals de Tortosa, que es podria justificar en llur creença que les obres de la nova seu anirien més ràpides i en la necessitat de prendre's tot el temps que calgués per poder trobar els millors mestres i, un cop trobats, contractar-los sense presses amb les millors condicions.

4. L'any 1379, havia mort el bisbe Guillem de Torrelles. L'ardiaca de Lleida, Bernat d'Olives, comissionat pel rei Pere III per recollir i conservar els drets pertanyents a la cambra apostòlica dins els seus dominis, havia fet empara de tots els béns mobles del bisbe de Tortosa que, "post eius mortem", havien quedat en poder del prior, ardiaca i degà de la Seu, nomenats marmessors seus en testament, i els havia exigit de lliurar-los a ell com a col-lector. Però el prior i dignitats de la seu van acudir en queixa al rei, assegurant que el bisbe, en vida, els havia encarregat de paraula de rebre els seus béns mobles i de pagar amb ells tots els deutes i que d'allò que encara sobrés fessin caritat per amor de Déu, encarregant-los també de fer-li una digna sepultura, de pagar als deutors $\mathrm{i}$ remunerar els familiars $\mathrm{i}$

\footnotetext{
${ }^{17}$ A. JosÉ PITARCH, Millenum, Barcelona, 1989, p. 279.
} 
servidors. El monarca els va atendre i, el 21 de març de 1379, manà a Bernat d'Olives que respectés la voluntat del bisbe difunt i deixés complir als marmessors els seus deures; que, segons la constitució de Tarragona, una part dels béns episcopals fos lliurada a l'obra i servei de la Seu -"et omnia ornamenta et iocalia que de dictis bonis solvi vel fieri habeant secundum constitucionem Tarracone ad opus ecclesie dertusensis"-, i que, del sobrant, ell rebés i conservés el corresponent a la cambra apostòlica ${ }^{18}$. Pere III acompanyà la decisió amb una ordre al veguer de la ciutat:

\section{Lo Rey.}

Veguer, nos, per causa, havem revocat lo manament que havíets fet ab gran pena als prior, arthiaca e degà de Tortosa per lo fet de la comissió de mossèn Bernat d'Olives, arthiaca de Leyda. Perquè us deym e us manam que aquest nostre revocament tingats e observets. Dada en Barchinona, a XXII dies de Març en l'any de la Nativitat de Nostre Senyor M CCC LXX VIIII. Rex Petrus.

Dominus Rex misit signatam ${ }^{19}$.

L'actitud exigent dels marmessors del bisbe Guillem de Torrelles exhibint els seus drets per possessionar-se de l'herència del bisbe difunt contrasta fortament amb llur capteniment a l'hora de complir els deures; perquè els procuradors i administradors de la sotstresoreria de la Seu de Tortosa van haver d'acudir al rei fent-li saber que els marmessors no havien lliurat a la seu ni els "vestimenta pontificalia" ni els "alia ornamenta que ipsi ecclesie Episcopus Dertusensis ultimo testamento, dum vivebat, facere debuisset" i que tampoc havien pagat les despeses del funeral i de la sepultura. El 8 de novembre de 1379, el rei manava al vicari general de la diòcesi "sede vacante" que forcés els marmessors a executar l'encàrrec testamentari ${ }^{20}$. Era aleshores ardiaca de Culla el canonge Pere Batlle ${ }^{21}$.

5. L'any 1380 , les obres de la Seu eren encara als seus inicis i, per tant, el rellotge mecànic que s'havia fabricat, que havia de guiar de nit i de dia amb el seny de les hores la vida privada i pública de la ciutat, no va poder-se instal-lar en cap punt de la nova construcció. La màquina del

\footnotetext{
${ }^{18} \mathrm{ACA}$, Cancelleria, reg. 805, fol. 97 v. -98 r.

${ }^{19} \mathrm{ACA}$, Cancelleria, reg. 805 , fol. $98 \mathrm{r}$.

${ }^{20} \mathrm{ACA}$, Cancelleria, reg. 808 , fol. 139 v. $-140 \mathrm{r}$.

${ }^{21} \mathrm{ACA}$, Cancelleria, reg. 1587, fol. $36 \mathrm{v}$.
} 
rellotge necessitava una cambra on guardar-se i almenys una espadanya per al seny de les hores. I això no podia existir en l'obra de la seu nova en un moment en què no eren ni tan sols cobertes totes les capelles de l'absis. Tenint en compte, a més, que els rellotges d'aquell temps necessitaven una atenció continuada, diària o quasi, per donar-los corda i posar-los a bona hora, l'escala d'accés al terrat era imprescindible. I no hi ha cap indici que l'única escala d'accés a la teulada de la seu nova, l'escala de cargol de la capella de Sant Pere, estigués aleshores ja acabada; i si ho estava, les obres en aquest sector no devien fer practicable l'escala per a un rellotger que havia de pujar-les cada dia o quasi per tenir en condret la màquina. Per tant, el rellotge va haver de ser col-locat a l'antiga seu, que en aquells anys encara era objecte d'adobaments i que no començaria a ser enderrocada fins a l'any $1428^{22}$.

La notícia de l'acabament del rellotge ens ve del fet que, l'any 1379 , Joan de Tornay, "magister aloretgiorum", va queixar-se al rei Pere III. El mestre rellotger exposava al monarca que, havent estat dispensat pel bisbe i pel capítol tortosins de pagar lloguer per una casa que li van assignar "ante construccionem arolotgii" perquè hi habités ell i hi fabriqués el rellotge "donec alorotgium ipsum perfectum esset", segons que havia estat acordat entre ells, Joan de Castre, canonge tresorer de la Seu, s'havia emparat de la casa esmentada, quedant-se una quantitat de diners i els béns mobles que hi havia, els quals eren propietat del rellotger, al-legant que ho feia per cobrar-se així el lloguer que el rellotger era dispensat de pagar. El 4 de gener de 1380, el rei manava al canonge tresorer de tornar al mestre rellotger els béns ocupats ${ }^{23}$.

Aquest mestre de rellotges, Joan de Tornay, "Johannes Alemanus, magister operis orlogiorum"24, originari d'Alemanya, i no pas "Juan

\footnotetext{
${ }^{22}$ Almuni, ob. cit., pp. 80-81.

${ }^{23} \mathrm{ACA}$, Cancelleria, reg. 806, fol. 111 r.v. Apèndix documental, núm. 1. Joan de Castre és enterrat al claustre de la catedral i es pot veure la seva lauda sepulcral adornada amb quatre escuts heràldics del seu cognom, representant-s'hi un castell de tres torres emmerletades, una major central i dues laterals menors, que emmarquen la següent inscripció: "Ací: iau: lonrat: en: Iohan: de: Castre: tresorer e: vicari: general: d'aquesta: seu: Obiit: a XVIII: dies: d'agost: anno: a nativitate: Domini: mil ${ }^{\circ}$ : $\operatorname{CCC}^{\circ}: \operatorname{LXXX}^{\circ}$ : tercio. Anima: eius: requiescat: in: pacem: amen:."

${ }^{24}$ M. Herrero García, El reloj en la vida española, Madrid, 1955, p. 4. Aquesta referència apareix publicada pr J. PASTOR, El reloj público, a "La Zuda", Tortosa, 31 de juliol de 1917.
} 
Alemany, relojero catalán (?)", com apareix en una nota de Joaquim Albas $^{25}$, prenent el gentilici pel cognom, havia fabricat, després del de Tortosa, el rellotge de la Seu de València, contractat amb ell pel bisbe i capítol el 10 de març de 1378 pel preu de 124 florins d'or d'Aragó ${ }^{26}$. L'any següent, el 28 d'abril, l'infant Martí el feia mestre de rellotges i familiar seu: "Quia fidei et devocionis puritas quam vos, fidelis noster Johannes de Tornay, Magister Arelogiorum, ad nostra servicia geritis ab experto. Et in vos urgens vestre artis habilis ac experta subtilitas vos apud nostram inclitudinem recomendat, volentes vos nostri familiaris titulo decorare"27.

El 27 de març de 1383, la ciutat de Tortosa donava en concepte de gratificació la quantitat de 2 lliures i 15 sous "an Domingo Vilar, prevere... per los treballs per ell sostenguts en tenir en condret lo relotge de la Seo"28.

En aquestes dates, més exactament el divendres sant de 1382, l'infant Joan, el primogènit del rei, era a Tortosa, venint-hi de Tarragona d'on havia sortit el dimecres sant, i va poder contemplar l'estat de les obres de la $\operatorname{seu}^{29}$.

6. N'ignorem la causa, però penso que té a veure amb les absències de l'obra del mestre Joan de Mayni la intervenció de Pere el Cerimoniós i Sibil·la de Fortià davant el capítol de la seu, el dia 11 de febrer de 1383, data en què els reis eren a Tortosa. El monarca expressà als canonges la voluntat que dirigís les obres, com a "maestre de la Seu", "Pere Ça Fàbrega, maestre de la Ciutat" ${ }^{30}$.

El municipi, coincidint amb la voluntat dels reis i discrepant del capítol, volia que el mestre de la seu fos el mateix mestre de la ciutat, creient que així s'assegurava la seva presència continuada a l'obra; el capítol, però, volia que fos mestre de la ciutat el mestre de la seu. I aquesta posició contrària havia creat divisions entre el prior i capítol de la seu i els representants de la ciutat. És per això que la reina advocà davant el capítol

\footnotetext{
${ }^{25}$ Luis Montañés Fontenla, Capítulos de la relojería española, Madrid, 1954, p. 62.

${ }^{26}$ Arxiu de la Catedral de València, vol. 3649, citat per Luis Montañés FonTEnLA, Capítulos de la relojería, pp. 61-62.

${ }^{27}$ ACA, Cancelleria, reg. 2068 , fols. 58 v. 59 r.

${ }^{28}$ Arxiu Municipal de Tortosa, Claveria, anys 1382-1383, fol. 236. Recollit per E. BAYERRI, Historia de Tortosa y su comarca, VIII, pp. 220-221.

${ }^{29} \mathrm{ACA}$, Cancelleria, reg. 1747, fol. $47 \mathrm{r}$.

${ }^{30} \mathrm{ACA}$, Cancelleria, reg. 1281, fol. 102 r.
} 
catedralici perquè per honor del rei, que els ho havia pregat i manat, rebessin "en Maestre de la vostra Seu en Pere Ça Fàbrega, maestre ja de la Ciutat." La carta reial diu que ell "solia ésser maestre en vostra seu" anteriorment a la data de la carta ${ }^{31}$.

Aquest és sens dubte el "mestre Pere", sense cognom, que Victòria Almuni ha trobat en els llibres d'obra com a mestre de la seu abans de l'any 1375 i, per tant, anterior a Andreu Julià. D'aquest mestre, fins ara, no hi havia notícia. Però, el 22 d'abril de l'any esmentat 1383, encara era mestre d'obres Joan de Mayni, destinatari de la carta del rei Pere, qui l'obliga a no marxar de l'obra de la seu ni emprendre cap altra obra abans d'acabar la capella de Sant Pere.

Pere de Mayni devia absentar-se sovint en detriment del bon desenvolupament de les obres de la seu; així ho recull el document reial: "E aprés és se seguit que un altre que hi havíets mes se'n és anat" ${ }^{32}$. Crec, doncs, que el mestre Pere Ça Fàbrega, que ja havia dirigit les obres de la seu abans, es fa càrrec novament de l'obra de la seu quan cessa, potser el mateix any 1383 , Joan de Mayni.

7. La construcció de les catedrals gòtiques era complexa i sovint presentava al mestres de l'obra problemes que requerien consulta amb uns altres mestres per trobar les solucions adients, tècniques o estètiques. Aquesta és la raó dels contactes i relacions que els mestres d'obra de la seu de Tortosa van tenir amb els mestres constructors d'altres edificis religiosos o civils de l'època: a) el viatge del mestre Bernat d'Alguaire a Avinyó i altres llocs per prendre model d'edificis i obres cara a la construcció de la nova seu tortosina ${ }^{33}$; b) el viatge del mestre Andreu Julià a Lleida, els anys 1375-1376, on va traslladar en un pergamí la "torre de Lleyda"34, referint-se, així ho creiem Almuni i jo mateix, al campanar de la Seu Vella, obra de Jaume Cascalls i Guillem Solivella, que, més tard, el 1414, visitaria també per prendre'n model per a la torre del Miquelet de València el mestre Pere Balaguer; i c) el viatge de Pascasi i Joan de Xulbi, el 1416, a Girona per participar, com a mestres de la seu de Tortosa, amb els mestres de

\footnotetext{
${ }^{31}$ ACA, Cancelleria, reg. 1587, fol. 173 v.

${ }^{32} \mathrm{ACA}$, Cancelleria, reg. 1281, fol. 102 r. Apèndix documental, núm. 3.

${ }^{33}$ AlmuNi, ob. cit., pp. 59, 113 i 153. Aquest viatge explicaria, segons Almuni, l'apropament de l'edifici de la catedral gòtica de Tortosa als esquemes constructius nòrdics, sense abandonar la tradició autòctona.

${ }^{34}$ Almuni, ob. cit., pp. 65, 113 i 153.
} 
Barcelona, Girona i altres, en la segona trobada de mestres d'obra dedicada a tractar qüestions relatives a la construcció de la gran nau de la catedral gironina ${ }^{35}$.

Hi ha, però, notícia d'una altra trobada de mestres a Tortosa, l'any 1375-76. La recull el llibre d'obra núm.3, al foli 61 v. i la publica Victòria Almuni dient que "dos mestres, un d'ells anomenat "Rocha"... es troben a Tortosa per motius professionals i dinen a casa del mestre de la seu"36. En no tenir més informació que aquesta i que el mestre Roca "participa en la primera de les consultes d'arquitectes sobre la nau de Girona... com a representant de l'obra de la seu de Barcelona", Almuni, molt prudent, afirma: "però cap notícia ens indica que la nostra cita es refereixi a la mateixa persona"37. Doncs, bé, aquest mestre Roca era certament Bernat Roca, el mestre de l'obra de la catedral de Barcelona, del sagrari i potser també de l'església dels Sants Just i Pastor, l'autor de l'altar major de l'església de la Mercè, prestigiós arquitecte gòtic que, en el temps de la seva primera visita coneguda a Tortosa, intervenia en les principals construccions de Barcelona, especialment en les obres dels Palaus Reials major i menor. Col-laborant amb ell l'escultor Pere Moragues, el mestre Bernat Roca realitzà els primers trams de la volta central de la galeria alta sobre les capelles de la catedral barcelonina, en va començar el claustre vers l'any 1382 i va enllestir gairebé en la seva totalitat els dos campanars el $1385^{38}$.

La visita a Tortosa crec que cal atribuir-la a motius professionals, cridat potser pel mateix mestre de la seu, qui el rebè a casa compartint estança i taula amb ell i amb un altre mestre que l'acompanyava, que ben bé podria ser el mestre Gabriel Segarra. La visita tingué lloc en temps que s'aixecaven l'absis i la girola.

El mestre Bernat Roca va tornar a Tortosa, on va poder veure el progrés de les obres de la seu i trobar-se novament amb el mestre de l'obra, aleshores potser Pere Ça Fàbrega, l'any 1388. Aquesta segona visita va tenir lloc, si no hi hagué impediment, durant els primers dies de febrer, cridat en aquest cas per la ciutat "per livellar, veure e consellar si és possible de traure e haver per cèquia aygua del flum d'Ebre per regar alguna partida del

\footnotetext{
${ }^{35}$ AlmUNi, ob. cit., pp. 113 i 153.

${ }^{36}$ AlmuNi, ob. cit., p. 113.

${ }^{37}$ Ibídem.

${ }^{38}$ MANOTE, entrada Bernat Roca, a Gran Enciclopèdia Catalana, 12, p. 648.
} 
terme de aquella Ciutat". Hi va acudir acompanyat del mestre Gabriel Segarra. Així li ho manava el rei Joan I en carta del 31 de gener de $1388^{39}$.

8. Quan va començar a aixecar-se la seu nova, la vida canonical i litúrgica seguia fent-se a la canònica, al claustre i a la seu romànica encara intacta, que ocupava l'espai actual de la capella de la Cinta i una part de les naus central i dreta de la catedral gòtica, la més pròxima al mur de la façana principal. Que el claustre era ja construït quan van començar les obres de la catedral nova queda provat pel fet que, segons costum, s'hi reunia el consell general de la universitat o municipalitat de Tortosa. I així es va fer "die Dominica, vigesima quinta junii, circa horam prandii" de l'any 1374, "convocata universitate dicte civitatis et singularibus eiusdem voce Johannis de Ulugia, preconis publici et jurati nuncii dicte civitatis, et per sonum tube, more solito, congregata in claustro dicte sedis, ubi ipsa universitas pro negociis communibus eiusdem peragendis convocari et congregari consuevit..." ${ }^{40}$.

L'estil i les dades documentals ens fan situar la construcció del claustre durant el segle XIII i creiem que ja era acabat en l'any 1262 quan, segons notícia recollida per Bayerri, el "Consell ple de la Universitat" va reunir-se "a les claustres de la Seu"41.

\section{El CAPÍTOL CATEDRALICI}

1. El capítol de canonges de la seu de Tortosa ha constituït sempre l'ànima vivent de l'edifici de l'església catedral, la mare de totes les esglésies de la diòcesi. El capítol ha estat el responsable de les iniciatives constructores, restauradores i reconstructores del temple catedralici i de les seves dependències annexes; la direcció col-legiada de les obres de construcció de la seu antiga i de la nova; la comunitat de canonges i beneficiats que ha vetllat secularment, com a consell del bisbe, pel bon regiment de la gran diòcesi que ha estat el bisbat de Tortosa fins al 1960. El capítol de canonges fou, així mateix, fins a l'any 1369, l'elector dels bisbes diocesans, els quals només podien ser triats entre els membres del col·legi

\footnotetext{
${ }^{39} \mathrm{ACA}$, Cancelleria, reg. 1833, fol. $10 \mathrm{r}$ - -v. Apèndix documental, núm. 2.

${ }^{40}$ ACA, Cancelleria, reg. 1242, fols. 24 r. -25 v.

${ }^{4 I}$ E. BAyerri Bertomeu, Historia de Tortosa y su comarca, VIII, p. 123.
} 
canonical; ha estat el mantenidor del culte litúrgic a la catedral amb el cant de les hores canòniques i la celebració de solemnes eucaristies amb participació dels fidels; i, com a resum de la seva tasca religiosa i cultural, ha estat i és el custodi del tresor preuat de la Santa Cinta i del ric Arxiu Capitular.

L'origen del capítol de canonges tortosí cal cercar-lo al segle XII, poc després de la conquesta de la ciutat de l'Ebre pel comte Ramon Berenguer IV, l'any 1148, quan el papa Adrià IV, el 20 de març de l'any 1155 , va confirmar la primera ordinació de l'església de Tortosa, aprovant alhora que el comte de Barcelona cedís al bisbe Gaufred, abat de Sant Ruf d'Avinyó, i als nou canonges que l'acompanyaven, terrenys per a edificar la catedral i la canònica. En efecte, el comte, el 1151, havia ja dotat l'església de Tortosa de béns suficients per al manteniment del bisbe i dels vint canonges que havien de constituir el capítol, signant el document de dotació el 5 d'agost.- En virtut d'aquest document els concedia el delme i la primícia dels fruits i dels animals, els terrenys i béns de la mesquita major $i$ de totes les mesquites que havien abandonat o en endavant abandonessin els sarraïns, i, a més, tots els delmes que corresponien al comte a Tortosa i dos forns de coure pa dins la ciutat.

La canònica, amb les dependències situades a l'entorn de la seu, va ser creada el 1153 com a comunitat regular regida per la regla de Sant Agustí del monestir de Sant Ruf d'Avinyó, amb un nombre inicial, encara teòric, de vint membres, als quals al·ludeix el papa Adrià IV - "XX fratres in conventu, qui pro te valeant Deum exorare"42. Gaufred arribava a Tortosa acompanyat de nou canonges, tots els quals, fent constar cadascun amb el nom la seva condició de "canonicus dertusensis", signen després d'ell la Prima Ordinatio Ecclesiae Dertusensis; aquests primers canonges eren: Pere, Guerau, Climent, Joan, Sanç i Bernat, preveres; Guillem, sotsdiaca; i Bartomeu i Guillem, levites ${ }^{43}$.

La Prima Ordinatio era l'acta pública del compromís canonical de viure segons la regla de Sant Agustí i guardar els usos i costums del monestir de Sant Ruf d'Avinyó. S'establia així mateix que en endavant no seria elegit bisbe de Tortosa ningú que no fos membre d'aquella canònica $i$ professés la regla augustiniana. Es decidia fundar un hospital per a pobres

\footnotetext{
${ }^{42} \mathrm{~J}$. VillanueVA, Viage literario a las iglesias de España, V, pp. 261-263.

${ }^{43}$ M. Risco, España Sagrada, 42, pp. 301-303.
} 
a càrrec de les rendes de l'església de Tortosa i amb una dotació que seria fixada a criteri del bisbe i dels germans canonges. I es definien les funcions dels càrrecs canonicals, els primers dels quals eren: prior, sacrista, cambrer, hospitaler i infermer.

Una Secunda Ordinatio, dictada pel bisbe Ponç de Mulnells d'acord amb el capítol el 21 de juny de 1166 , precisava encara més les funcions, el règim de vida i l'administració canonicals i dividia les rendes del bisbe de les dels canonges, creant-se així la "mensa episcopalis" i la "mensa canonicalis". El capítol es reservava com a propietat la canònica i el claustre de la seu amb les dependències annexes. Així mateix es disposava que els bèns canonicals eren comuns, que el bisbe havia de prendre aliment de la cuina dels canonges i que el capítol s'havia de fer càrrec dels béns del bisbe, que passaven a ser propietat de l'església quan aquest havia mort, excepció feta dels béns mobles, que podien distribuir-se segons la voluntat del difunt. El capítol s'obligava a viure pobrament, a atendre l'hospital de pobres, que havia de tenir el mateix metge que els capitulars, i a socórrer altres menesterosos ${ }^{44}$.

2. El capítol de canonges tortosí, l'any 1178, havia celebrat solemnement amb la ciutat el coronament de les obres de la seu romànica, consagrada pel bisbe Ponç de Mulnells el 28 de novembre en presència d'Alfons I el Cast i la reina Sança. L'any següent, la nit del 24 al 25 de març de 1179, segons antiga tradició, un beneficiat i el prior del capítol van ser testimonis i dipositaris del prodigi de la baixada i presència de la Mare de Déu dins l'antiga seu tortosina i del lliurament de la Santa Cinta ${ }^{45}$.

La construcció de la nova catedral i el culte que bisbes, capítol i poble hi han retut han estat il-luminats des de bon principi per la presència i custòdia devota de la Santa Cinta de la Mare de Déu, joiós encàrrec del prior i capítol catedralicis. Del mateix any en què va posar-se la primera pedra de la catedral gòtica, el 1347, és l'inventari, anomenat "Inventari antich de les Santes Relíquies" de la seu tortosina, on apareix en detallada descripció "la Santa Cinta de Nostra Senyora":

\footnotetext{
${ }^{44}$ R. O'Callaghan, Anales de Tortosa, pp. 227-229. L'original de la Secunda Ordinatio es guarda a l'Arxiu Capitular de Tortosa. E. BAYERRI BERTOMEU, Historia de Tortosa y su comarca, VIII, pp. 431- 433.

${ }^{45}$ Arxiu de la Catedral de Tortosa, Breviari de la Catedral, Venècia, 1507. Ofici de la Mare de Déu de la Cinta. Caixa de la Santa Cinta, núm. 5.
} 
Item te el Monge major, en una caixa de fusta pintada, una Cinta, la qual se diu esser de Sta. Maria, la qual es de seda blanca, et es feta a manera de exarsia de pescar, la qual presta a les dones que van en part et no poden enfantar, et es nuada en sinch llochs et hay 12 palms de llonch e mes de 1 de ample, e hals caps es feta a manera de trena fil, o de cairell, et hai un tros de cuiro lligat a cada un cap a 4 palms, la qual se diu que Sta. Maria la ha tinguda cintada en esta Iglesia, com hic apparet, segons que pus llongament es contingut en un miracle, lo qual es escrit en alguns llibres segons ques diu ${ }^{46}$.

Fundada la sotstresoreria de la seu l'any 1354, va formar-se nou inventari, autoritzat pel notari Pere Sunyol, on quedà enregistrada, entre altres relíquies, aquesta: "Item la Recinta de Madona Sancta Maria, la qual està en una caixeta de fust, és la Recinta de seda"47.

En l'inventari del 1420 ja es parla d'un reliquiari de plata: "...un reliquiari d'argent sobredaurat, ab got de crestall engastat al cap, en què és la Cinta de la Verge Maria e, sobre lo got una creveta d'argent daurada ab vuyt perles grosses, e, al peu del reliquiari dotçe pedres en floretes d'argent blanques engastades"48.

El tema de la Santa Cinta no podia faltar entre els plafons esculturats del retaule de la Mare de Déu de l'Estrella, el retaule que la ciutat de Tortosa, l'any 1351, havia determinat de construir per a l'altar major de la nova seu. Segons Aureli Querol, canonge i prior de la Santa Cinta, el retaule gòtic conté un plafó que mostra de forma convencional i esquemàtica l'aparició de la Mare de Déu amb la Santa Cinta: "la Virgen entre dos ángeles y sobre nubes y entregando la Santa Cinta a un hombre de pie que levanta su brazo derecho para recibirla." No descarta tampoc que el plafó contigu a l'anterior, on es representa una processó amb pontífex i tàlem de vares, mostri la processó de la Santa Cinta, si bé podria ser la del Corpus atès que falta gairebé sencer l'objecte que el pontífex duu a les mans, així com, al plafó anterior, falta també la cinta a les mans de la Mare de Déu esteses en actitud de lliurament ${ }^{49}$.

3. Resseguint els llibres de la Cancelleria Reial corresponents a la segona meitat del segle XIV i primeries del XV, època de gran activitat

\footnotetext{
${ }^{46}$ M. Jover Flix, La Santa Cinta de Tortosa, Tortosa, 1978, p. 51.

${ }^{47}$ E. BAYERRI BERTOMEU, ob. cit., VII, p. 489.

${ }^{48}$ Ibídem, p. 490.

${ }^{49}$ M. JOVER FLIX, ob. cit., pp. 49-50.
} 
constructora a la seu, el capítol de canonges apareix sovint com a protagonista de fets eclesiàstics, culturals i administratius d'importància.

De vegades trobem el capítol patint injerències i fins $i$ tot violència en la seu, en la canònica o en algun dels seus membres ${ }^{50}$; en altres ocasions el trobem veient amb goig la promoció d'algun capitular a càrrecs de confiança reial o a càrrecs i beneficis eclesiàstics. No hi falten les eleccions de bisbe anul-lades pel papa, amb les lògiques tensions dins el capítol, ni les conseqüències del Cisma d'Occident experimentades amb dolor pels capitulars, sobretot en temps de "sede vacante", afegint-s'hi les derivades de la calculada indeterminació reial respecte als papes elegits a Roma i a Avinyó. Entre aquestes conseqüències cal considerar les més greus l'absència perllongada del bisbe de la diòcesi i l'elecció simultània de dues persones per a l'episcopat tortosí. De tot hi hagué en l'època que estudiem.

Les intervencions reials afectant el capítol de la seu tortosina són nombroses, gairebé totes motivades pel cisma de l'Església. Així, el 14 d'abril de 1380, Pere III, assabentat de la vacant canonical existent per mort del canonge Joan Espuny, escrivia al prior i capítol de l'església de Tortosa en defensa dels drets de Berenguer Ferrer, el qual, "vigore specialis gratie domini Gregorii, bone memorie, pape undecimi" va acceptar la dignitat canonical "post electionem Urbani et ante electionem Clementis tamquam ille qui in causa cernitur esse prior". El dret l'afavoria d'acord amb el resultat de les respostes donades a la consulta règia "per maiorem partem prelatorum nostri dominii existentium pridem in curia nostra et alios nonnullos pontifices et viros prudentes". El rei fa valer a favor de Berenguer Ferrer la no revocació de la gràcia pel papa Climent i la indiferència o neutralitat reial, exigida també al capítol - "quare neutri duorum in summum pontificem electorum obedimus, immo sumus indiferentes super hiis, sicuti sitis"respecte a l'elecció de dos cardenals per a la dignitat pontifícia. Per això i "propter servitia per ipsum nobis impensa" el monarca prega i mana al capítol que el rebi "in canonicum et in fratrem sub habitu regulari"51.

\footnotetext{
${ }^{50}$ L'any 1405 , la canònica fou escenari de bregues $\mathrm{i}$ atacs armats entre dues faccions de ciutadans, una de les quals era afavorida $\mathrm{i}$ protegida pel tresorer $\mathrm{i}$ altres clergues de la seu (ACA, Cancelleria, reg. 2235, fol. 70 r.-v.). Pocs anys després, el 1409, eren presos Pere Palau, Jofre Gilabert, Jaume Cantó i Guillem Penedès, inculpats d'haver assassinat el canonge tresorer, Marc d'Esplugues, "qui sub velo convivii in quodam molendino vocato de Alcacer detinebatur", i de violar la salvaguarda reial de Joan de Prats, "infirmario et officiali Episcopi" (ACA, Cancelleria, reg. 2236, fol. 116 r.-v.).

${ }^{51} \mathrm{ACA}$, Cancelleria, reg. 812, fols. 27 v. $-28 \mathrm{r}$.
} 
Però hi ha notícia d'injerències del rei Pere el Cerimoniós des dels mateixos inicis del seu regnat, molt abans del cisma. Una carta reial adreçada al capítol des de Perpinyà el 30 d'octubre de 1351, motivada pel càrrec de consciència que afectava el rei, dóna fe que el capítol havia elegit per a bisbe de Tortosa el seu prior, Francesc de Montoliu, a la mort del bisbe Bernat Oliver el 1348, però el rei s'hi oposà i va recomanar al papa la persona de Jaume Sitjó. L'elecció del capítol fou anul-lada pel papa, i Jaume Sitjó fou nomenat bisbe en lloc de Francesc de Montoliu. A la mort de Sitjó, el 1351, el rei volia esmenar la injustícia donant suport a l'elecció del capítol, que un cop més va recaure en la persona de Montoliu, però aquesta vegada fou el papa Climent VI qui, malgrat la recomanació reial, anul-là l'elecció capitular i nomenà bisbe de Tortosa el bisbe d'Elna, Esteve Malet. Pere III ho havia comunicat així al capítol tortosí i n'encarregava la recomanació als ambaixadors davant el papa de Roma:

\begin{abstract}
... Francesch de Muntoliu, prior de Tortosa, fo, en temps passat, elet per lo capítol de Tortosa en bisbe de Tortosa e nós, aquella vegada, pregam per altre, e per aquesta raó ell no pogué obtenir lo dit bisbat; nós, com sabem quel bisbe de Tortosa ()$^{52}$, suplicam al Sant Pare per letra escrita de nostra mà, la qual vos havem tramesa per en Montoliu, quen degués proveir al prior dessús dit perquè e per ço com delavons ençà, segons quel capítol de Tortosa nos ha escrit per sa letra, altra vegada és estat lo dit Francesch de Muntoliu elet per aquell capítol en bisbe de Tortosa, nós no volem revocar los prechs en favor del dit Francesch de Muntoliu per nós ja fets... ans vos manam aytant com pus espressament podem que vosaltres presentets la letra en favor del dit Francesch feta al dit Sant Pare. E instets e supliquets al papa que dia al dit Francesch provehir del bisbat dessús dit en guisa que la nostra consciència d'açò sia descarregada... ${ }^{53}$
\end{abstract}

El 23 de febrer de 1370, vuit anys abans del cisma, el rei Pere havia demanat al papa la concessió graciosa d'una dignitat canonical a la seu de Tortosa a favor de la persona de "Michaelis Rovira, clerici barchinonensis diocesis, baccallarii in artibus, etatis XVI annorum, cupientis in ecclesia dertusensi, ordinis Sancti Augustini, dicto sub religionis habitu famulari" sol-licitant que "eundem Michaelem in ecclesia predicta, ubi certus est canonicorum numerus institutus, si desit vel cum defuerit aliquis de dicto

\footnotetext{
${ }^{52} \mathrm{El}$ document presenta aquí una llacuna. Hi hauria de dir "era mort".

${ }^{53} \mathrm{ACA}$, Cancelleria, reg. 1138 , fol. 88 r.-v.
} 
numero, recipi faciatis in canonicum et in fratrem, et habitum religionis tradi et sicuti uni ex aliis canonicis dicte ecclesie provideri"54.

El 17 de febrer de 1373, el rei Pere, alarmat per la notícia que el papa nomenés un estranger bisbe de Tortosa, signava un protocol d'ambaixada a la cort pontifícia que contenia, entre altres, aquest capítol:

Capítols d'açò quel religiós frare Thomàs Olzina, ministre del orde dels frares menors de la província d'Aragó ha a dir al Sant Pare per vigor de la creença quel Senyor Rey li ha comanada (...) Item li diga de part del Senyor Rey el suplich que dels bisbats de sa senyoria proveesca a sos naturals e no a persones estranyes. Car lo Senyor Rey ha entès quel Pare Sant volia l'altre jorn provehir del bisbat de Tortosa a I avesque d'altra nació, e és gran vergonya e dampnatge de sos sotsmesos que ells no hagen les prelacions quils són degudes per bona raó, maiorment car lo Pare Sant sab bé que ell no promou negú de la terra del dit senyor a dignitats d'altres terres. E axí bé seria raonable cosa que nols degués tolre aquestes que deuen haver ${ }^{55}$.

Aquesta situació no es podria haver donat si s'haguessin observat les ordinacions del capítol i bisbat de Tortosa segons les quals el bisbe havia de ser elegit entre els membres del capítol de la seu.

El 25 de febrer de 1377, el monarca escrivia al papa Gregori XI demanant-li que concedís l'honor de Mestre en Teologia i la "insignia Magistratus" a frare Francesc Marmany, O.P., lector de la seu de Tortosa, el qual "gramaticam, logicam et naturalem scientiam successive docuerit per sex annos deinde tam intra ecclesiam cathedralem Dertuse, cuius lector extitit, quam intra diversos conventus sui ordinis per XII annos legerit Theologiam feceritque cursum suum completum in studio generali sue ordinis Barchinone utpote quin ibidem fuit biblicus bacallarius, magister studentium et lector principalis regens cathedram dicti studii generalis" ${ }^{156}$.

El 27 de maig del mateix any el rei demanava una canongia a la seu de Tortosa per a Joan de Barbaran, fill de Guillem de Barbaran, graduat a Oxford $^{57}$. El 10 de maig de 1378, s'interessava per la persona, família i

\footnotetext{
${ }^{54} \mathrm{ACA}$, Cancelleria, reg. 1232, fol. $3 \mathrm{v}$.

${ }^{55} \mathrm{ACA}$, Cancelleria, reg. 1236, fols. $120 \mathrm{v} .-121 \mathrm{v}$.

${ }^{56} \mathrm{ACA}$, Cancelleria, reg. 1233, fol. 105 r.-v.; reg. 1254, fol. $54 \mathrm{v}$.

${ }^{57} \mathrm{ACA}$, Cancelleria, reg. 1233 , fols. 114 v.-115 r.; 164 v.-165 r.
} 
béns de "Berengarius Serrat, canonicus ecclesie dertusensis"58. El mateix dia sol-licitava al papa una canongia a la seu de Tortosa o en una altra catedral per al seu familiar, Joan Morera, "scolaris in gramaticalibus studentis, diocesis dertusensis" ${ }^{\prime 9}$. I en idèntica data el rei Pere demanava al papa una dignitat, si podia ser, major que l'episcopal per a la persona de "Petri de Sancto Amancio, canonici et hospitalarii Ecclesie Dertusensis, ordinis Sancti Augustini"60. També demanava un benefici simple, "vocatum diaconale, in eadem Ecclesia Dertusensi", per a Domingo Vilar, clergue tortosí ${ }^{61}$. Pere de Sant Amanç, a instància del rei Joan I, rebria del papa avinyonès la gràcia de l'ardiaconat de Daroca, amb la irregularitat que en el document de concessió havia estat "fraudulosament mudada la data"62.

El 23 de juny de 1376, Pere III feia saber al prior i capítol de Tortosa la voluntat de Bernat Nadal, clergue, familiar i domèstic del rei, d'entrar a formar part de la comunitat de la seu: "cupit sub habitu regulari in Ecclesia nostre civitatis Dertuse Domino famulari"63.

4. L'any 1378 començava el cisma d'Occident. Pere III, l'any següent, pren la determinació de no decidir-se per cap dels dos papes elegits, quedant indiferent a tots dos, actitud que exigeix també de tots els seus súbdits. A més de quedar-se amb el control i l'administració dels béns de la cambra apostòlica, el rei jugarà amb avantatge en demanar gràcies i beneficis als dos papes, acollint-se sempre, en cas de conflicte, a la decisió papal més favorable. De moment, però, calia estar-se tothom a les ordinacions del papa Gregori XI, com ho escriu al seu cosí, el comte de Prades, el dia primer d'octubre de 1379: "car nos, ab consell dels prelats havem determenat que negunes gràcies d'aquests dos quis dien papes no sien obeïdes dins nostra senyoria mentre nós estigam indiferents. Mas que entretant prenguen los empetrants de papa Gregori, e que com empetrants de papa Gregori noy haia, los ordinaris donen los beneficis"64. Així s'assegurava, per exemple, que el rector Pere Ricard mantingués la possessió de l'església de Tivissa.

\footnotetext{
${ }^{58} \mathrm{ACA}$, Cancelleria, reg. 1233, fols. 139 v. -140 .

${ }^{59} \mathrm{ACA}$, Cancelleria, reg. 1233, fol. $151 \mathrm{r}$.

${ }^{60} \mathrm{ACA}$, Cancelleria, reg. 1233, fol. $153 \mathrm{r}$.

${ }^{61} \mathrm{ACA}$, Cancelleria, reg. 1233, fol. $158 \mathrm{r}$.

${ }^{62} \mathrm{ACA}$, Cancelleria, reg. 1833, fol. 23 v.

${ }^{63} \mathrm{ACA}$, Cancelleria, reg. 1254, fol. $35 \mathrm{v}$.

${ }^{64} \mathrm{ACA}$, Cancelleria, reg. 1265 , fols. 45 v., 120 v.; reg. 1266, fols. 29 v. $-30 \mathrm{r}$.
} 
Recent obert el cisma, l'any 1379 moria el bisbe Guillem de Torrelles, l'activador de les obres de la seu. El capítol feia despeses en "draps negres per a l'enterrament" ${ }^{65}$. El bisbe havia mort deixant nombrosos deutes, que calia pagar dels seus béns ${ }^{66}$, i amb la vigència d'unes penes d'interdicte i excomunicació imposades per ell contra els de Calaceit pels atemptats que aquests havien fet als habitants de la masada de l'Amenla, propietat de la seu de Tortosa, que defensaven els drets d'herbatge dins el terme de Calaceit.

El rei Pere III, el 7 de desembre de 1380, davant la mort del bisbe, volent acabar el contenciós entre l'orde de Calatrava i el capítol tortosí, va escriure als vicaris del bisbat $i$ al prior i capítol de la seu de Tortosa perquè l'afer del conflicte jurisdiccional acabés amistosament.

Mort el bisbe, l'infant Joan, primogènit i lloctinent del rei, s'apressava a escriure dues cartes molt semblants, l'una al capítol de la seu de Tortosa i l'altra a Ombert de Fonollar, exposant-los la voluntat que el seu confessor, fra Francesc Rafard, fos elegit bisbe de Tortosa. El text de la carta adreçada a Ombert de Fonollar el 21 de febrer de 1379, era aquest:

\footnotetext{
Lo primogènit.

Sabents nos que vostre oncle lo Bisbe de Tortosa és passat d'aquesta vida, pregam ab altra letra nostra, la qual vos trametem ensemps ab aquesta, los del Capítol de la seu de la dita ciutat de Tortosa que per honor nostra e mèrits del religiós e amat conseller e confessor nostre frare Francesch Rafart, lo elegesquen en bisbe d'aquella mateixa seu. Perquè volem e us pregam e manam espressament que ab la major diligència que porets instets e procurets ab acabament quels dessús dits facen la dita elecció (...).

Dada en Barchinona, sots nostre segell secret, a XXI de fabrer de l'any $1379^{67}$.
}

Pere III constatava una degeneració moral prou ràpida a partir de la mort del bisbe Torrelles, que calia frenar i ell atribuïa a la falta de visites pastorals: "Quodque ab obitu dicti quondam Episcopi citra, ex deffectu visitationis que fieri solebat per Episcopum per loca et parochias diocesis

\footnotetext{
${ }^{65} \mathrm{ACA}$, Cancelleria, reg. 1265, fol. $139 \mathrm{v}$.

${ }^{66} \mathrm{ACA}$, Cancelleria, reg. 805 , fol. 105 r.-v.; reg. 806 , fols. 4 v. -5 r., 50 v. -51 r., 144 r.v., 157 v.-158 r.; reg. 807 , fols. 146 v.-147 v., 155 v., 159 r.-v.; reg. 810 , fol. 84 r

${ }^{67} \mathrm{ACA}$, Cancelleria, reg. 1745 , fols. 188 v. -189 r.
} 
Dertuse, crimina usurarum, adulterii et alia peccata seu delicta pullularunt et incessanter commituntur." I per això, com a senyor del territori, concedia llicència i autoritat a qui fos nomenat per fer visites pastorals a la diòcesi: "Etiamque quare dignum et necessarium fore arbitramur ut parochie et loca dicte diocesis pro corrigendis peccatis et criminibus visitentur, volumus et consentimus ac vobis concedimus quod ille qui ad hec fuerit assignatus visitet dicta loca et parochias et quod illi tali sumptus et expense circa dictam visitationem necessarii ex emolumentis ex dictis peccatis seu criminibus perventuris exsolvantur et administrentur"68.

El rei, contra les constitucions capitulars, pretenia que fos nomenat bisbe de Tortosa, i així ho esperava obtenir del papa, Guillem Galceran de Rocabertí, canonge cabiscol de Girona i batxiller en decrets. El rei ho feia saber al capítol ${ }^{69}$. Els canonges, però, van elegir per a bisbe el prior Miquel Cirera, natural de Morella. El papa d'Avinyó, Climent VII, va anul·lar l'elecció capitular i elegí Hug de Llupià i Bages, canonge i paborde de la seu de València, "in legibus licenciati, prepositi Valencie", al qual, com a bisbe de Tortosa, escrivia ja Pere III el 24 de juny de $1379^{70}$. El bisbe Hug, de València estant, el 27 d'abril de 1382, escrivia al rei donant-li informacions confidencials ${ }^{71}$. Però Hug de Llupià, residint a cavall de València i de la cort papal d'Avinyó, no prendria possessió de la seu de Tortosa fins al 4 de febrer de l'any 1387, obrint-se una etapa llarga d'absència episcopal a la gran diòcesi. Un cop més, la indiferència reial envers els papes de Roma i Avinyó es deixa sentir pesant sobre la diòcesi tortosina i el capítol de canonges. I molt em temo que la lentitud de les obres de la seu no fos deguda tant a la manca de recursos com a la desorientació administrativa i pastoral del capítol de canonges, desmoralitzats per la situació que els pertocava de viure i pels conflictes que en derivaven.

La situació cismàtica s'estenia fins als darrers racons de l'Església. A Tortosa en tenim, entre tantes, una mostra molt significativa: A la mort del bisbe Torrelles, el papa Climent VII d'Avinyó, havent anul·lat l'elecció feta pel capítol, proveí de bisbe de Tortosa Mossèn Hug de Llupià alhora que el papa Urbà, de Roma, proveí Mossèn Ramon Cervera. El rei Pere III,

\footnotetext{
${ }^{68} \mathrm{ACA}$, Cancelleria, reg. 816 , fols. 46 v. -47 r.

${ }^{69} \mathrm{ACA}$, Cancelelria, reg. 1266, fol. 2 v.

${ }^{70} \mathrm{ACA}$, Cancelleria, reg. 1266, fol. $10 \mathrm{r}$; reg. 1281, fol. $27 \mathrm{v}$.

${ }^{71} \mathrm{ACA}$, Cancelleria, reg. 1274, fol. 45 r.
} 
encara indefinit respecte al papat, de Barcelona estant, el 7 de juliol de 1380, manava que no hom donés possessió a cap dels dos elegits per a bisbes de Tortosa exigint al capítol que la seu romangués vacant "entro que nós nos siam determenats"72. I el rei no es determinà mai per cap dels dos papes, mantenint la seva neutralitat - "indiferentia" - fins a la mort. Així, doncs, la seu de Tortosa quedaria vacant per força temps. Xoca, però, amb l'actitud del rei la de l'infant Joan, el primogènit, el qual, més sensible a la mala situació del bisbat, el 10 de maig, des de Perpinyà, havia escrit al rei i a la reina suplicant-los que el bisbe de Tortosa pogués prendre possessió del bisbat i dels seus béns ${ }^{73}$. La súplica no fou atesa, però l'actitud de l'infant Joan honora la seva persona. Confirma, al meu parer, la consciència $i$ sensibilitat de l'infant Joan el fet que, ja rei, dispensés el bisbe de Tortosa, Hug de Llupià, tants anys absent de la diòcesi, d'acompanyar-lo a Sardenya, malgrat que el bisbe li havia manifestat la voluntat de fer-ho ${ }^{74}$. Era una manera de fer-li veure que el seu lloc com a bisbe era el bisbat que havia de regir com un bon pastor.

Era el dia 11 d'abril de 1381 quan el rei Pere escrivia des de Saragossa als col-lectors dels rèdits i drets pertanyents a la Cambra Apostòlica dins el bisbat de Tortosa ordenant-los que paguessin almenys la meitat de les despeses del prior i de l'ardiaca de la seu tortosina que, en nom de la seu i capítol, havien anat a Saragossa, cridats pel rei, com molts altres prelats i eclesiàstics, "ratione determinationis quam facere, dante Domino, intendimus cui ex illis duobus electis in papam obedire debeamus et reputemus justum..."75.

No faltarien reunions i trobades amb aquest ordre del dia. Però el monarca no es determinaria mai, la qual cosa ens fa sospitar molt de la sincera voluntat reial, sobretot si ens adonem de la calculada estratègia, que sempre jugava a favor del monarca, i de les conseqüències que en derivaven, també beneficioses per als seus interessos. Entre altres fets, valgui aquest com a mostra: L'any 1380, el rei assaja una nova pràctica que emprarà fins a la mort i és la de mantenir la mateixa relació amb els dos papes, el de Roma i el d'Avinyó; així, en l'any esmentat, dóna curs a sengles peticions

\footnotetext{
${ }^{72} \mathrm{ACA}$, Cancelleria, reg. 1268, fol. $67 \mathrm{r} . \mathrm{-v}$.

${ }^{73} \mathrm{ACA}$, Cancelleria, reg. 1656, fol. $132 \mathrm{v}$.

${ }^{74} \mathrm{ACA}$, Cancelleria, reg. 1960, fols. 107 v. $-108 \mathrm{r}$.

${ }^{75}$ ACA, Cancelleria, reg. 1269 , fol. 19 r.
} 
de capellanies als papes Climent VII, d'Avinyó, i Urbà VI, de Roma, a favor de clergues súbdits seus, entre els quals hi ha, en primer lloc, Mossèn Pere Pasqual, rector i fill de la Fatarella, prevere, capellà reial, per a qui demana la provisió "de canonicatu... Ecclesie Barchinonensis"76.

Vacant la capellania comensal de Sant Andreu de la seu de Tortosa per mort del prevere Guillem Ferrer, "cuius capellanie collatio spectat ad Cardinalem de Agrifolio", Pere III, el 10 de juny de 1381, escrivia al prior i capítol demanant-los que, quan hi hagués vacant algun benefici o canongia que pertoqués a ells de concedir, la concedissin al seu recomanat, "cum nos teneamur dilecto capellano nostro Francisco Botellerii, magistro Gramatice Sedis Dertuse", diu el rei ${ }^{77}$. El 14 de març del mateix any, escrivia al prior i capítol demanant-los que donessin a Ramon Granell, clergue tonsurat de Tortosa, el benifet sots invocació de Sant Andreu, que hi havia vacant a la seu $^{78}$.

Del mateix any, el 1383, en què apareix a la documentació de la Cancelleria Reial "Pere Ça Fàbrega" com a "maestre de la Seu i de la Ciutat"79, és la dedicació protectora del rei Pere a favor de Simó de Prades, "unum ex filiis" del físic reial Simó de Prades, "magistro in Medicina", "studentem in Studio Ilerdensi", el qual volia ser promogut al sacerdoci; el rei, de Tortosa estant, el 4 de gener, sol-licitava al capítol de la seu de Lleida i al bisbe electe, Ramon d'Escales, que li concedissin una canon$\mathrm{gia}^{80}$. Una petició semblant havia estat feta pel rei al prior i capítol de la seu de Tortosa, als quals, en carta signada a Montsó el dia 11 d'octubre de 1383, exposava la queixa personal pel fet que "la canongia que vagava per mort den Johan de Castres, tresorer de vostra seu" l'haguessin donat a un prevere $\mathrm{i}$-diu el rei- "no havets volgut provehir a son fill del maestre Simon de Prades, per lo qual vos havem escrit en haviem fets justa petició per N'Arnau Torrelles, cambrer nostre, ne en Bernat Menjavaques, per qui així mateix vos havem escrit"81.

\footnotetext{
${ }^{76} \mathrm{ACA}$, Cancelleria, reg. 1266, fols. 75 v. -76 v.

${ }^{77} \mathrm{ACA}$, Cancelleria, reg. 1269, fol. 122 v.; reg. 1271, fols. 47 v. -48 r.

${ }^{78} \mathrm{ACA}$, Cancelleria, reg. 1274, fol. $5 \mathrm{r}$.

${ }^{79} \mathrm{ACA}$, Cancelleria, reg. 1281, fol. $102 \mathrm{r}$.

${ }^{80} \mathrm{ACA}$, Cancelleria, reg. 1281, fol. 54 r.-v.

${ }^{81}$ ACA. Cancelleria, reg. 1281, fol. $132 \mathrm{v}$.
} 
L'atenció reial envers els fills de Simó de Prades venia de lluny i era tan gran la voluntat d'afavorir-los que, l'any 1371, el rei ja els volia proveir d'algun benefici o canongia. El 12 de gener de l'any esmentat, el rei Pere III escrivia al papa Gregori XI demanant una canongia de la seu de València o de Lleida per a Pere de Prades, "studentis in logica, filii Simonis de Prades, in artibus et medicina magistrati, phisici nostre domus, tonsurati clerici"; i demanava el mateix a favor de la persona de Simó de Prades "in sede Dertusensi, aut in sede Tarraconensi aut in Cesaraugustana" 82.

El rei no protegia només persones. Buscava també el prestigi del capítol catedralici procurant la promoció dels seus canonges a les dignitats de la seu i també a altres honors i càrrecs, com els abacials, els episcopals i fins i tot els cardenalicis. Així, el 22 de desembre de 1373, suplicava al papa la concessió d'una dignitat canonical a la mateixa seu de Tortosa a favor de Joan Ballester, "canonicus in Ecclesia Dertusensi, canonicus regularis ordinis Sancti Benedicti ac actu in Studio Ilerdensi in iure canonico studentis"83. El 30 d'agost de 1377, demanava al papa de Roma dignitats eclesiàstiques, almenys canonicals, en alguna de les seus de la Corona d'Aragó, per als seus capellans reials Pere Pasqual i Miquel de Guàrdia encarregant-ne la procuració i recomanació al Cardenal d'Aragó, Pedro de Luna ${ }^{84}$.

Del prestigi del capítol i dels seus membres el rei obtenia també favors $\mathrm{i}$ beneficis quan els cridava a consulta, quan els enviava com ambaixadors o quan demanava els seus serveis per a alguna obra cultural. Així, el 13 de gener de 1358, Pere III escrivia al prior i capítol de la seu de Tortosa fent-los saber que havia escollit per a una ambaixada reial el lector de Teologia i demanant-los la corresponent dispensació "cum nos pro aliquibus arduis negotiis nostris religiosum et dilectum nostrum fratrem Guillelmum Cunilli, lectorem Sacre Theologie in sede Dertusensi, ad partes remotissimas in presentiarum providerimus transmittendum..." 85.

El 31 de juliol de 1371, el monarca escrivia al "Magister Petrus de Moros, prevere, beneficiat en la seu de Tortosa", mestre de lletra formada, interessant-se per un breviari diurnal que li havia encarregat:

\footnotetext{
${ }^{82} \mathrm{ACA}$, Cancelleria, reg. 1553, fols. 3 v. -4 r.

${ }^{83} \mathrm{ACA}$, Cancelleria, reg. 1553, fol. 30 v.

${ }^{84} \mathrm{ACA}$, Cancelleria, reg. 1553, fols. 50 v. $-51 \mathrm{r}$

${ }^{85} \mathrm{ACA}$, Cancelleria, reg. 1070, fol. 82 r.
} 


\begin{abstract}
Lo Rey. Manam vos que, si havets acabat d'escriure lo diornal que a obs nostre screvits, si no quel acabets com pus prestament porets, et aquell nos aportats de continent, car nos sens altra dilació vos farem pagar tot ço que a vos sia degut per treball d'escriure aquell e totes messions que vos haiats fetes en aportar lons axí per loguer de bèstia com per altra rahó. Dat en València sots nostre contrasegell lo derer dia de juliol del any M CCC setanta e un. Rex Petrus.

Dominus Rex mandavit mihi Berengario Segarra. Probata ${ }^{86}$.
\end{abstract}

Les recomanacions de persones davant el papa o els bisbes eren també pròpies de la reina i responien generalment, suposada la vàlua dels recomanats, a la voluntat de premiar amb càrrecs i dignitats eclesiàstics la fidelitat i els serveis prestats als monarques. Aquest és el cas de la recomanació que fa, el 23 de març de 1379, davant el bisbe electe de Tortosa, la reina Sibil·la de Fortià a favor de la persona de "Manuel Pujol, fill d'En Ramon Pujol quondam, de Tortosa", pels favors i serveis que feien a la reina els seus parents i amics, sol-licitant-li la concessió d'una canongia, aleshores vacant ${ }^{87}$. Semblantment, la reina signava a Tortosa, el 2 de gener de 1383, un escrit adreçat a "Na Sterona, muller de Jacme Sabater, patrona d'un benifet a la seu de Tortosa", en què li comunicava "que el capítol ha provehit d'una canongia an Johan Siurana, lo qual obtenia aquest benifet"; la reina li demanava que el concedís a "Pere Sabater, escolà de la nostra capella... pels serveis quens ha fets e ens fa continuadament"88. Joan Siurana era el canonge morellà que, en ser traslladat a València el bisbe Hug de Llupià l'any 1398, seria elegit pel capítol per a bisbe de Tortosa, elecció que anul-laria el papa Benet XIII.

El 2 de maig del mateix 1383, havent mort Pere de Santamanç, "qui era hospitaler de Tortosa", la reina Sibil-la escrivia al prior i capítol de la seu demanant-los d'admetre "en lo dit ofici d'hospitaler i les rendes de l'hospitaleria" la persona que el rei Pere havia designat. El rei havia encomanat "lo regiment e administració del ofici de la dita hospitaleria a N'Arnau de Blanes, canonge e enfermer del monestir de Santa Maria de Vilabertran"89.

\footnotetext{
${ }^{86} \mathrm{ACA}$, Cancelleria, reg. 1085, fol. $99 \mathrm{v}$.

${ }^{87} \mathrm{ACA}$, Cancelleria, reg. 1587 , fol. $37 \mathrm{r}$.

${ }^{88} \mathrm{ACA}$, Cancelleria, reg. 1587, fol. 167 r.-v.

${ }^{89} \mathrm{ACA}$, Cancelleria, reg. 1587 , fol. $187 \mathrm{v}$.
} 
El dia 1 de setembre del mateix any, Sibil-la de Fortià demanava al papa Climent VII d'Avinyó la concessió de la tresoreria de la seu a Bernat de Menjavaques, "iurisperitus diocesis dertusensis, homo antiquus, providus et honestus, qui, licet in consiliis regiis et aliis interfuerit aut consenserit morti et mutilationi membrorum virorum et mulierum, licite tamen iuxta consuetudinem huius terre, residuum tamen tempus vite sue vellet ecclesie servitio exhibere". Per ell es pregava la dispensa papal "super inhabilitate" de manera que pogués ser rebut de seguida a la professió canonical i proveït de la tresoreria de la seu. El motiu del favor reial era que el personatge recomanat havia estat "unus inter alios consiliarios et auditores curie domini regis, viri et domini nostri carissimi, quibus ipse et nos valde afficimur" i la reina el considerava "satis competens pro eodem officio thesaurarie". La súplica al papa era presentada quan ja vacava la tresoreria: "cum nunc vaccet locus in ecclesia dertusensi, que est regularis ordinis Beati Augustini, videlicet officium thesaurarie pro obitu Johannis de Castris, canonici et thesaurarii eiusdem" 90 .

5. L'any 1387 , va morir Pere el Cerimoniós i va quedar enterrada amb el seu cos la indiferència o neutralitat reial en la qüestió del cisma. El rei Joan es va posar del costat del papa d'Avinyó, al qual va donar l'obediència dels seus dominis després d'escoltar les opinions d'una assemblea de teòlegs i juristes convocats aquell mateix any a Barcelona. El capítol veia esvair-se de l'horitzó el núvol d'incomoditat i d'incertesa, motiu freqüent de desorientació, que la neutralitat del rei Pere havia engendrat. Ara bé, les negatives conseqüències del cisma seguirien pesant sobre el capítol i la diòcesi de Tortosa fins a l'any 1418 .

L'absència de bisbe, conseqüència del cisma i de la neutralitat del Cerimoniós, havia obligat el capítol de la catedral, la setmana santa del 1381, a sol-licitar la presència del bisbe Francesc Janer, o. m., bisbe de Konavlje, a la Dalmàcia ${ }^{91}$, desplaçat "pro ministrandis ibidem pontificalibus sacramentis pridem de villa Perpiniani... apud dictam Sedem Dertusensem". Però l'actitud del capítol no fou en aquest cas honesta perquè, havent fer venir a Tortosa el bisbe, "qui ad magnam instantiam venit", un cop va ser a la ciutat li van dir que no el necessitaven; per la qual cosa, dels 50 florins

\footnotetext{
${ }^{90} \mathrm{ACA}$, Cancelleria, reg. 1588 , fol. $68 \mathrm{r}$.

${ }^{9} \mathrm{C}$. EUBEL, Hierarchia catholica medii aevi, I, p. 218. Fra Francesc Janer havia estat consagrat el 20 de desembre de 1372.
} 
d'or que li havien promès per les despeses i incomoditats del llarg viatge, només li'n van lliurar 25, assegurant-li que els altres 25 els farien a mans durant el mes de juny. El mes d'abril de 1382, després de nombroses reclamacions, el bisbe encara no havia cobrat aquesta segona quantitat ${ }^{92}$.

Per la setmana santa de 1383, va acudir a Tortosa, "sede vacante", per fer-hi els serveis pontificals de la consagració dels olis sants, l'arquebisbe de Torres, qui va cobrar el servei pastoral dels fons de la cambra apostòlica. El rei Pere li havia promés vint florins d'or d'Aragó i va manar al mestre racional, Bernat Calopa, "reebedor e administrador general dels béns o drets pertanyents a la cambra apostolical", de pagar-li puntualment els florins assignats ${ }^{93}$.

La mateixa situació es repetirà l'any 1401 , en temps del rei Martí, quan tenia l'administració del bisbat tortosí el nebot del papa Benet XIII, Pero de Luna, el qual va ser imposat al capítol i no tenia la dignitat episcopal. El rei li escrivia el 6 de març aprovant i agraint-li molt "la comissió que per honor e complaença nostra havets feta al Reverend Pare en Crist e amat conseller nostre l'Arquebisbe de Thenes en ministrar órdens e fer tots altres serveis pontificals en loch e persona vostra en l'Esgleya vostra e bisbat de Tortosa"94.

6. L'administració apostòlica del bisbat a mans de Pedro de Luna, nebot del papa i cosí de la reina Maria de Luna, va comportar tensions i nombrosos problemes al bisbat i en el si del capítol. Els capitulars van entendre que en anul'lar l'elecció per a bisbe del canonge Siurana i lliurar l'administració de la diòcesi a Pedro de Luna, es jugava amb els drets del capítol, el prestigi i la dignitat de les persones i el bé de la diòcesi tortosina. I així era.

Pedro de Luna havia pres possessió de l'administració de la diòcesi l'any 1399. Aquell mateix any, el rei Martí, que lamentava la situació creada a Tortosa, tant de temps castigada amb l'absència de bisbe, va fer tot el possible davant el capítol de canonges de la seu perquè Pedro de Luna fos consagrat bisbe; fins i tot va enviar-los el seu conseller i camerleng Mossèn Lop Ximénez de Urrea; però el capítol s'hi negà. El capítol era integrat

\footnotetext{
${ }^{92} \mathrm{ACA}$, Cancelleria, reg. 1727, fol. 150 r. Apèndix documental, núm. 6.

${ }^{93} \mathrm{ACA}$. Cancelleria, reg. 1458, fol. $117 \mathrm{r}$. Apèndix documental, núm. 5. L'arquebisbe de Torres, a Sardenya, era aleshores el menoret Joan de Fornells, "magister Theologie", consagrat el 14 de desembre de 1373 (EuBEL, Hierarchia, I, p. 504).

${ }^{94} \mathrm{ACA}$, Cancelleria, reg. 2172, fol. $166 \mathrm{r}$.
} 
aleshores per 16 membres ${ }^{95}$. De res valgueren tampoc les súpliques insistents i fins i tot amenaçants adreçades al prior i capítol per la reina Maria de Luna intercedint pel seu cosí a partir del mes de maig de $1399^{96}$. De fet, la reina Maria havia demanat el bisbat de Tortosa per al seu cosí des del mateix moment en què el trasllat a València d'Hug de Llupià l'havia deixat vacant. Així es desprèn del text de la carta que, el 18 de desembre de 1398, havia enviat a Benet XIII agraint-li la promoció del "venerabilis Patris Hugonis, olim Dertusensis Episcopi, ad Ecclesiam Valentinam", en la qual es queixa "cum in eo nondum fuerit nostra supplicatio exaudita quod instantius petebamus quodque non minus nostro est insitum animo nobilem scilicet Petrum de Luna, legum egregium professorem, Sanctitatis Vestre nepotem et consanguineum nostrum percarum, ad Cardinalatus apicem provehi cum provisione Dertusensis ecclesie in casu translationis premisse, remanentibus sibi necminus cum ipsa ecclesia beneficiis omnibus que hodie possidet et quod ultra illa alia etiam usque ad equivalentiam Valentine ecclesie ei beneficia conferentur..." ${ }^{97}$.

Les cartes de Maria de Luna anaven adreçades explícitament a tot el capítol de la seu i a cadascun dels capitulars: Al prior major, Joan Siurana, a Joan Amargós, ardiaca, a Pere de Ferrera, infermer, a Guillem Ramon, degà, a Andreu Coscó, precentor, a Joan Ballester, prior claustral, a Berenguer Serrat, canonge, a Berenguer Çolivelles, canonge, a Pere de Garret, a Vicenç Segarra, "Decretorum doctori", canonges, i a Miquel Segarra, Francesc Gil, Jaume Scapolat, Bernat Guasch, Bernat Company i Berenguer Pineda, canonges de la seu de Tortosa ${ }^{98}$.

La primera carta de la reina al capítol, en llatí, era signada a Saragossa el 8 de maig de 1399. Maria de Luna expressa l'interès del rei i propi, exposats al papa Benet XIII des del moment del trasllat del bisbe Hug de Llupià a València, perquè Pedro de Luna fos consagrat bisbe i li fos atorgat el bisbat de Tortosa. Justifica l'interès per la seva persona en raons de parentiu - "... respectu debiti parentele, quo nobis est junctus vir nobilis Petrus de Luna, decretorum professor, domini Summi Pontificis nepos..."i en la vàlua humana, intel·lectual i moral de la seva persona - "...Petrus

\footnotetext{
${ }^{95}$ ACA, Cancelleria, reg. 2171 , fols. 123 v.-124 v.

${ }^{96}$ ACA. Cancelleria, reg. 2336, fol. 80 r.-v'.

${ }^{97} \mathrm{ACA}$, Cancelleria, reg. 2348, fol. $119 \mathrm{r}$.

${ }^{98} \mathrm{ACA}$, Cancelleria, reg. 2337 , fols. 42 v. -43 r.; reg. 2171 , fols. 123 v. -124 r.
} 
ipse, in quem nobilitas generis, amicorum potentia, scientie profunditas, vite et morum honestas, industria circumspecta et alie quoque dotes virtutum uberrime fluere dinoscuntur". La carta té el to de la súplica afectuosa i manifesta l'esperança d'aconseguir el favor del capítol basant-se sobretot en la dignitat de la peticionària, en la forma de demanar-lo, en la satisfacció que donaria al papa $\mathrm{i}$ als reis la seva concessió $\mathrm{i}$ en els fruits que rebria l'església de Tortosa del bisbe Luna. I no podia faltar, com no hi falta, la promesa de recompensar amb gràcies i favors el capítol i cadascun dels seus membres si la súplica era atesa:"Quare tamen omnia cupimus ad huiusmodi provisionem concurrere que illam deceant, solident et honestent, vos tamen et quemlibet vestrum cordialiter deprecamur quatenus, premissorum intuitu et dicti domini pape et nostri respectu honoris, velitis Petrum eundem, de quo dicte vestre ecclesie firma potestis, dante Domino, expectare fiducia optime provideri, eligere in vestrum et ipsius ecclesie presulem et pastorem"99.

El capítol va ignorar la carta de la reina Maria, la qual s'havia assabentat ja de la negativa capitular a elegir Pedro de Luna per a bisbe i de l'elecció feta en la persona del prior major, Joan Siurana, que Benet XIII, descaradament influït per la reina, va anul-lar. Molesta pel silenci i actitud dels capitulars, Maria de Luna els adreçava una altra carta, aquesta en català, el 30 de maig. Dolent-se alhora del fet que "encara no són exausits los prechs no poch affectuosos del Senyor Rey, marit e senyor nostre molt car, e nostres, que us faem d'aquests jorns per nostres letres de e per la elecció de nostre car cosí don Pedro de Luna... en bisbe e pastor vostre e de la vostra esgleya de Tortosa", la reina els feia saber que no entenia i, a més, rebutjava l'actitud del capítol en elegir Joan Siurana, la qual cosa atribuïa al fet de ser "decebuts alcuns per pròpia cupiditat e alcuns per inducció d'altres". Per això, en opinió de la reina, que així reprèn els capitulars i els dóna un impertinent alliçonament, "havets feta e fets collusió o colligança de e sobre elecció faedora d'altre, de què, si axí és, fort meravellada per les raons dessús dites, e car ne pendríets masse gran càrrech e de no poca e assenyalada descomplacència e ingratitud del Sant Pare e del Senyor Rey, als quals davant tots altres, atteses maiorment les dites coses, ne devets gratificar e complaure".

\footnotetext{
${ }^{99} \mathrm{ACA}$, Cancelleria, reg. 2337, fols. 42 v.-43 r. Apèndix documental, núm. 9.
} 
La carta, que mostra un to agre, adquireix un to desafiant quan la reina s'atreveix a afirmar, òbviament de manera fictícia o amb una gran ignorància, que "esperem fermament e siam en cert quel papa provehirà, si ia no hi ha provehit, al dit nebot seu de la dita esgleya e per consegüent no li fos necessària la elecció dessús dita." Oblidava la reina Maria que Benet XIII era un excel·lent jurista i un home recte? De fet, el papa Luna no va consagrar bisbe de Tortosa el seu nebot contra la voluntat del capítol, a favor del qual eren les ordinacions del bisbat. I Pedro de Luna no seria consagrat bisbe fins a l'any 1405, dos anys després d'haver estat proveït de l'arquebisbat de Toledo ${ }^{100}$. De seguida, però, la reina busca aconseguir del capítol l'acceptació de la proposta perquè, "foragitada tota ambició pròpia e tota sinistra suasió squivada", diu als capitulars, "façats la dita elecció canònicament, liberalment e prompta" i d'aquesta manera "concórreguen en la sua provissió dessús dita totes coses que aquella soliden e honesten" ${ }^{101}$.

La reina era profundament compromesa en l'afer; tant que no parava d'escriure al papa i al capítol. El 20 de juny, enviava a Benet XIII una nova carta d'urgència en uns termes que mostren la seva impaciència i desànim: "...supplicamus iterum et iterum quanto humilius et cordialius possumus quatenus supplicationem dignemini regiam, depulsa mora quacumque, liberaliter exaudire"102. I el mateix dia, amagant els seus sentiments de frustració, escrivia novament al capítol de Tortosa en resposta a una carta que aquest li havia fet arribar explicant els motius de l'oposició a l'elecció de Pedro de Luna; els motius no eren altres que la prohibició de les ordinacions del bisbat, és a saber que, com diu la carta, "no pot ésser elegit ne postulat en bisbe d'aqueixa esgleya sinó canonge reglar vestit d'hàbit canonical". La reina no cessava en l'intent d'afavorir el seu cosí. I altre cop exhibeix davant el capítol la inutilitat de la seva oposició i de l'elecció de Siurana "... veents que elegir o postular altre no profeteria res com siam certa quel papa, son oncle, provehirà a ell, si ja nol ha provehit, e no a altre de la dita esgleya." I acaba l'escrit pregant els canonges d'abstenir-se en tota elecció o postulació ${ }^{103}$.

\footnotetext{
${ }^{100}$ C. EuBel, Hierarchia, I, p. 482 . Pedro de Luna fou consagrat bisbe pel mateix Benet XIII, "patruo suo", el 5 de juliol de 1405 (EUBEL, Hierarchia, I, p. 223).

${ }^{101} \mathrm{ACA}$, Cancelleria, reg. 2337, fols. 47 v. -48 r.

${ }^{102} \mathrm{ACA}$, Cancelleria, reg. 2337, fol. 55 r.-v.

${ }^{10.3} \mathrm{ACA}$, Cancelleria, reg. 2337, fol. 55 r.-v.
} 
Per document reial del 8 de juliol de 1400 sabem que "Johan Amargós, artiacha de la seu de Tortosa" anava a Avinyó per tractar "amb el Pare Sant sobre alguns negocis arduus de la dita seu"104. En aquell moment, els negocis ardus de la seu i del capítol no eren altres que l'anul-lació papal de l'elecció capitular i la imposició al capítol d'un administrador diocesà, que el capítol rebutjava. Però no solament això. Sabem, per la documentació reial, que hi havia mala maror en el si del capítol, el responsable de la qual era precisament l'ardiaca Amargós, qui, després de l'elecció del prior Siurana, "per enveia o malvolença del dit Prior elet o postulat", havia escrit una carta on deia, entre altres coses, que Siurana, volent posar el bisbat a mans del rei, havia promès grans quantitats de diner al monarca buscant que aquest li donés possessió del bisbat. El 19 de gener de 1403, el rei Martí escrivia al papa fent-li saber aquest afer i que enviava Jaume de Prades a Avinyó perquè l'informés de la greu calúmnia escrita i difosa pel canonge Amargós. Una altra carta explicant l'afer era adreçada el mateix dia a Jaume de Prades. No podem descartar que l'anul-lació de l'elecció del prior Siurana per a bisbe fos deguda a l'afer de l'ardiaca i a la seva influència ${ }^{105}$.

La situació requeria l'aplicació de tota la diplomàcia del rei. És obvi que calia apartar el canonge Amargós de l'administrador apostòlic, del capítol i del territori de domini reial. I l'ocasió per fer-ho la brindava el fet que uns moros de Berberia havien robat de l'església de Torreblanca la custòdia amb les sagrades formes que s'hi guardaven, les quals havien portat al seu país. Martí l'Humà no ho pensà dues vegades $i$, en carta del 6 de juny de 1399, signada a Saragossa, ordenà a l'ardiaca Amargós d'anar en ambaixada al rei de Tunis, acompanyant el conseller i camerleng reial Pere de Queralt, "per recobrar les Santes Eucaristies": "E com lo dit noble partesque d'ací de present e vaja en Barchinona per recollir-se dins lo present mes de juny, pregam vos tan affectuosament com podem e us requerim de part de Déu que anets e siats per tot lo mes de juny en Barchinona per recollir-vos e fer ab lo dit noble lo dit viatge..." ${ }^{100}$. No sabem, però, si l'ardiaca va complir la voluntat reial i, en cas de complir-la, quant de temps va ser fora de la diòcesi.

\footnotetext{
${ }^{104}$ ACA, Cancelleria, reg. 2291, fol. $10 \mathrm{v}$.

${ }^{105}$ ACA, Cancelleria, reg. 2291, fol. 165 r.-v. Apèndix documental, núms. 7 i 8.

${ }^{106}$ ACA. Cancelleria, reg. 2242, fol. 134 r.
} 
Mentrestant havia mort Pere de Garret, canonge infermer i rector de Batea, i el rei Martí, el 16 d'octubre de 1401, demanava al papa Benet XIII, també al papa Bonifaci IX, per a la "infirmarie ecclesie supradicte, que nunc vacat in curia", la promoció de fra Berenguer Serrat, "canonicus Ecclesie Dertusensis, ordinis Sancti Augustini, vir literatus, moribus illustratus, facundia decoratus, in divinis officiis mirabiliter eruditus, in administratione temporalium comprobatus et aliis virtutum donariis multipliciter insignitus". Simultàniament, per assegurar-se l'ocupació de la dignitat vacant, el 17 d'octubre, la sol-licitava per a Llorenç Manresa, "baccallarius in Decretis" 107 .

I el 5 de desembre de 1403, escrivia a Benet XIII demanant l'ardiaconat de Culla, vacant "per obitum Cardinalis Pampilonensis", per a Jaume Scapolat, "canonicus Ecclesie Dertusensis, in decretis baccallarii antiqui actuque legentis extraordinarium Decreti in studio Montispesullani". El valor anual de l'ardiaconat, diu el document reial, no excedia aleshores la quantitat de 350 florins d'or d'Aragó ${ }^{108}$.

Pedro de Luna, només prendre possessió de l'administració apostòlica, havia nomenat vicari general seu a Tortosa, - greu provocació per al capítol i el prior Siurana- l'ardiaca Joan Amargós ${ }^{109}$; més tard, nomenaria el prevere Ramon Cirera, "licenciato in decretis"110. A més, qualsevol actuació del nou administrador era feta d'esquena al capítol i en no pocs casos contra les ordinacions i la voluntat dels capitulars.

Ens descobreix aquesta manera desconsiderada de procedir, ultra el nomenament de Joan Amargós com a vicari general, la carta que el rei Martí adreçà a l'administrador apostòlic, signada a Valldaura el 2 d'octubre de 1400 , queixant-se de la gosadia injusta de treure de lector de la seu el que havia elegit el capítol per imposar-ne un altre nomenat per ell. Els termes de la carta clarifiquen molt bé com procedia l'administrador apostòlic i quin menyspreu havia de patir el capítol catedralici: "Rei Martí. A Pedro de Luna, administrador perpetual de l'Esgleya de Tortosa. Entès havem que a

\footnotetext{
${ }^{107}$ ACA, Cancelleria, reg. 2291, fols. 89 r.-v., 93 v.-94 r. Al reg. 1928, fol. 130 r.-v. es recull la petició que, el 28 de febrer de 1396, Joan I va elevar al papa demanant per a Llorenç Manresa, "fidelis de nostra capella, clericus dertusensis diocesis", una canongia a la seu de Tortosa.

${ }^{108}$ ACA, Cancelleria, reg. 2292 , fol. 15 r.

${ }^{109} \mathrm{ACA}$, Cancelleria, reg. 2211 , fol. $40 \mathrm{v}$.

${ }^{110} \mathrm{ACA}$, Cancelleria, reg. 2152, fols. 63 v. -64 r.
} 
la ciutat de Tortosa és vengut Maestre Johan Sanç, del orde dels preycadors, axí ab letres vostres com d'altres, volent gitar de la lectoria de l'Esgleya de Tortosa lo religiós e amat nostre frare Anthoni dez Puig, qui ha la dita lectoria a sa vida axí per concessió del capítol com a fundador de la lectoria dessús dita com per confirmació del Maestre General del dit orde (...) E com sie cosa per ús perpetual e antigada que algú no pot ésser lector si no és de la província, e lo dit Maestre Johan no sie de la província d'Aragó mas de Prohença..." ${ }^{\prime \prime \prime}$, el rei, defensant els drets del capítol, va prohibir a l'administrador diocesà el canvi de lector de la seu.

L'actuació de Pedro de Luna no devia agradar tampoc gaire al rei Martí, preocupat, a més, per l'absència de bisbe a la diòcesi. El monarca, el 13 de gener de 1401, li escrivia en aquests termes:

\begin{abstract}
Don Pedro, recorda'ns que per mossèn Pere Ça Garriga vos havíem tramès a pregar de paraula que lexàssets o comanàssets la administració de la vostra esgleya e bisbat de Tortosa a mossèn l'Archabisbe d'Atenes, nostre conseller e antich servidor, axí com a aquell per lo qual som certs que la dita esgleya serà ben regida en aquells temps de l'any que és de necessitat axí en donar òrdens com en altra manera haver prelat president en cascuna esgleya cathedral, e havem sabut per letres del comanador de la Mercè de Perpenyà que vós havets respost al dit mossèn Pere que per nostra reverència vós ho faríets sinó car vos ne era ja stat parlat en favor de un bisbe framenor qui era a Tarragona per semblant administració d'aquella esgleya. E som maravellats que en aquest cas ni en altres sie mesa paritat de pregàries a les nostres a instància d'alguna altra privada persona, e que de semblant cosa no'ns sie complagut per vós... ${ }^{112}$
\end{abstract}

La carta acaba demanant una prompta resposta afirmativa a la petició reial. El 10 de febrer, el rei li havia d'escriure una nova carta perquè Pedro de Luna no havia respost a la primera ${ }^{113}$.

El malestar del capítol per la situació creada a la diòcesi amb la imposició de l'administrador Pedro de Luna es fa palès en la documentació de la Cancelleria Reial de l'època. I aquest malestar va durar fins i tot més enllà del temps en què Pedro de Luna va ser administrador del bisbat. La raó és que el seu oncle, Benet XIII, li va concedir plens poders sobre tots els

\footnotetext{
"IIACA, Cancelleria, reg. 2172, fols. 109 v. $-110 \mathrm{r}$

${ }^{112} \mathrm{ACA}$, Cancelleria, reg. 2211, fol. $39 \mathrm{v}$.

${ }^{113} \mathrm{ACA}$, Cancelleria, reg. 2211, fol. 44 r.-v.
} 
béns que administrava a Tortosa fins a poder disposar dels béns de la mitra de Toledo: "cui possessionem bonorum mensae episcopalis Toletanensis nondum assecuto, (...) ut interim redditus mensae episcopalis Dertusensis vendere, impignorare, arrendare et etiam in suam utilitatem assignare possit, non obstante quod Ludovicus, episcopus Majoricensis, ad Dertusensem translatus fuerit"114.

Després de l'administrador Pedro de Luna fou nomenat bisbe de Tortosa Lluís de Prades, bisbe de Mallorca, però aquest no va voler deixar el bisbat illenc i el rei Martí, el 22 de febrer de 1407, demanà al papa el bisbat de Tortosa per "al nostre canceller, micer Francesc de Blanes, doctor en decrets, referendari del Sant Pare del bisbat de Taraçona". Així ho exposava en la carta: "El car cosí nostre En Loys, bisbe de Mallorques, recuse acceptar lo bisbat de Tortosa, al qual ere transportat, elegint romanir en lo bisbat que posseeix d'aqui avant"115.

Lluís de Prades, impulsor de les obres de la catedral de Ciutat de Mallorca, no va prendre mai possessió del bisbat tortosí i no és comptat entre els seus bisbes. Ignorem les raons de la seva negativa a acceptar el trasllat, però crec que podria haver-lo influït el coneixement de la situació del bisbat, sotmès a llargs períodes de "sede vacante", a les tensions originades per la imposició de l'administrador apostòlic i la seva actuació de govern, i amb els béns de la mitra en mans de Pedro de Luna, béns que Lluís de Prades no podia administrar tot $\mathrm{i}$ haver estat nomenat bisbe de Tortosa ${ }^{116}$.

L'any 1403, però, el papa nomenà bisbe de Mallorca Francesc Climent Sapera. consagrat el 17 d'agost d'aquest any, el qual, havent regit el bisbat de les Illes fins al 1407, fou nomenat bisbe de Tortosa el 20 de juny de 1407 i hi exercí el càrrec fins al 1410, quan fou traslladat a la seu de Barcelona. En ser traslladat a Tortosa Francesc Climent, Benet XIII nomenà per segona vegada bisbe de Mallorca Lluís de Prades.

7. Com podem veure, doncs, el capítol tortosí, com els altres de la Corona d'Aragó, no solament coneixia injerències dels monarques i no

\footnotetext{
${ }^{114}$ Eubel, Hierarchia, I, p. 223, nota 4. Lluis de Prades, "notarius apostolicus in ecclesia Valentina, baccallarius in Decretis, clericus", nomenat bisbe de Mallorca el 28 de juny de 1390 va ser nomenat bisbe de Tortosa el 20 de juny de 1407 (EUBEL. Hierarchia, I, p. 323), després del trasllat de Pedro de Luna a Toledo el 30 de juliol de 1403 (EubEL, Hierarchia, I, p. 487).

${ }^{115}$ ACA, Cancelleria, reg. 2182 , fols. 66 v. -68 r.; 82 r.-v.: 86 v. -87 r.

${ }^{116}$ Archivium Vaticanum, 326, f. 303. Citat per Eubel, Hierarchia, I, p. 223, nota 4.
} 
poques amargors originades arran de l'exercici de l'administració imposada de Pedro de Luna; també va rebre els beneficis de la protecció reial. Algunes mostres ja les coneixem, però he volgut deixar per al final d'aquest article les proves que he trobat més significatives de l'afecte, interès i preocupació reials envers el capítol, la seu i la diòcesi.

Alguns canonges $i$ beneficiats de la seu tortosina van ser associats pels monarques a la casa reial com a capellans, escolans de la capella $i$ domèstics. Aquest fou el cas de Jaume Ballester, beneficiat de la seu, dispensat de servir el benefici pel bisbe Guillem de Torrelles perquè pogués dedicar-se a la capellania reial; servia el benefici per ell, com a procurador, el prevere Domingo Guillem ${ }^{117}$.

El canonge Joan Ballester era conseller de l'infant Martí, duc de Montblanc, i el rei Joan I, el 27 de juliol de 1390, va proposar-lo al bisbe i capítol per a la dignitat d'hospitaler de la seu ${ }^{118}$.

El 29 d'octubre de 1392, el rei Joan demanà al papa Climent VII que concedís a Miquel Segarra, canonge de Tortosa i capellà reial, de ser capellà d'honor de la Seu Apostòlica'119.

La capella de la Mare de Déu de la Petja i el benefici instituït allí per Guerau de Montbrú, ardiaca de Culla de la seu de Tortosa, eren objecte de la devoció i afecte de Joan I quan, el 19 de novembre de 1393, el rei escrivia al papa sol-licitant les gràcies pontificals sobre la capella i els devots de la Mare de Déu que hi anessin a venerar-la: "...perpetuam capellam heremitanam in termino civitatis Dertuse, in partita que dicitur de la Petja, in qua, sub invocatione Beate Marie, quoddam instituit beneficium... ad quam quidem capellam magnus concursus habetur civium dicte civitatis ob devotionem quam ibi habent..." El rei demanava al papa Benet XIII, "ad augmentationem devotionis", la concessió d'indulgència a la capella i a tots els que la visitessin "...in illis festivitatibus de quibus in vestra cancellaria est solitum concedere cum clausulis opportunis ut in forma"120.

Joan I, que havia fet capellà i domèstic seu el canonge Miquel Segarra, en data del 8 d'agost de 1393 l'autoritzava a portar, ell i els dos escuders que amb ell vivien i l'acompanyaven, espases i qualssevol armes

\footnotetext{
${ }^{117}$ ACA. Cancelleria, reg. 1275, fol. 25 r.-v.

${ }^{118}$ ACA. Cancelleria, reg. 1875, fol. $53 \mathrm{r}$.

"1"ACA. Cancelleria, reg. 1881, fol.51 r.-v.

${ }^{120} \mathrm{ACA}$. Cancelleria, reg. 1885, fols. 62 v. -63 r.
} 
prohibides $^{121}$. Així mateix, el 5 d'octubre de 1394, el monarca aprovava i lloava l'elecció del canonge de Tortosa, Bernat de Vernet, per a abat del monestir de Sant Pere d'Ager, aleshores canonja augustiniana ${ }^{122}$.

El 23 d'octubre de 1406, el rei Martí donava protecció a la persona i als familiars, als béns i drets del canonge Joan Siurana, "prioris ecclesie dertusensis", existents a la vila de Morella ${ }^{123}$.

El 26 d'abril de 1408, el monarca publicava la seva adhesió al misteri de la Immaculada Concepció de Santa Maria Mare de Déu en els mateixos termes amb què l'havia defensat el seu germà, el rei Joan I. Alhora inculcava la devoció a la Puritat de Maria i manava als bisbes i capítols de la Corona d'Aragó que es fes celebració solemne de la festa el 8 de desembre a totes les catedrals i esglésies. El capítol de la seu de Tortosa rebia una nova carta reial, com l'havia rebut abans del rei Joan, instant-lo a la celebració litúrgica mariana ${ }^{124}$. El rei havia signat la carta a València el 18 de desembre de 1402 i feia saber al capítol que. "instantia nonnullorum civium" de Tortosa, "qui erga cultum honoremque precipuum Conceptioni dicte Sacratissime Virginis impendendos zelo fervide devotionis et fidei more christianissimo adducuntur", estava assabentat que "in civitate predicta, de Conceptione Beate Marie Virginis, matris Christi Domini Salvatoris, nullum cantatis seu cantari facitis jubilum solemnitatis festive prout in aliis nostri regni civitatibus ex ordinatione nostra est iam fieri consuetum." El monarca els manà que prediquessin al poble sobre el misteri de la Puríssima Concepció el dia de la seva festa, celebradora cada any a perpetuïtat "sub officio duplici"125.

El 14 de setembre de 1406, el monarca atorgava la seva protecció sobre el capítol tortosí, fent objecte del benefici tots els membres de la comunitat, la canònica, els representants legals, els seus familiars i servidors i tots els seus béns i propietats, mobles i immobles: "...administratorem, capitulum, canonicos ac presbiteros, diaconos, subdiaconos et clericos ac alios quoscumque beneficiatos in Sede Civitatis Dertuse, necnon vassallos, familiares, comensales et domesticos, procuratores, nuntios, factores,

\footnotetext{
${ }^{12}$ ACA. Cancelleria, reg. 1886, fol. $1 \mathrm{r}$.

"2ACA. Cancelleria, reg. 1886, fol. $146 \mathrm{r}$.

${ }^{123} \mathrm{ACA}$, Cancelleria, reg. 2151 , fols. 58 v. -59 r.

${ }^{124} \mathrm{ACA}$. Cancelleria, reg. 2183 , fols. 54 r. -55 r.: $59 \mathrm{v}$.

${ }^{125}$ ACA. Cancelleria, reg. 2212, fol. 17 r.-v.
} 
defensores et negotiorum gestores, census redditus, castra, loca, domos, agraria, fructus, iura, animalia tam grossa quam minuta"126.

Martí l'Humà, commogut ja abans pel llarg temps en què la diòcesi tortosina havia patit la privació de bisbe, conseqüència del cisma i de la neutralitat de Pere III, i ara per l'absència personal del bisbe Francesc Climent Sapera, nomenat el 1406 però que seguia residint a la cort papal d'Avinyó, el 22 de gener de 1409 escrivia a Benet XIII en termes dramàtics demanant-li que deixés d'oblidar l'església de Tortosa, la qual, diu, "sola sedet et expers thori sponsi sui, qui per orbem vagatur, ducit quare vidua in planctibus et singultibus dies suos." I li afegia amb patètica eloqüència: "Enim, vero, Sanctissime Pater, hec per Sanctitatem Vestram non debent equanimiter tolerari. Eam quippe latere non credimus quod a longevis citra temporibus iam dicta ecclesia, orba suo pastore, lupis rapacibus cogitur ancillari, ex quo nedum sibi sed civitati Dertuse evidentia damna et scandala sunt secuta et sequi sperantur multo maiora propter bandositates ingentes ibidem suscitatas nisi sepedicta Sanctitas aliter duxerit ordinandum. Quapropter eidem Sanctitati humiliter supplicamus quatenus, ut imminentibus scandalis occurratur, Episcopo civitatis ipsius mandare dignetur expresse quod, quibusdam negotiis postergatis, de facto visitet sponsam suam et cum ea ducat in gaudio de cetero dies suos..." ${ }^{127}$.

\section{CONCLUSIÓ}

El període que va del 1345 al 1417, any de l'acabament del Cisma d'Occident, fou per al capítol de canonges i per al bisbat de Tortosa un temps força mogut. Fou temps de molta activitat constructiva, de vegades lenta o amb aturades transitòries, a l'obra de la nova seu. Hi hagué llargs períodes d'absència del bisbe perquè la seu estava vacant o perquè el bisbe era a la cort d'Avinyó. Les intervencions protectores i també d'injerència per part dels reis sobre el bisbat i el capítol foren abundants, generalment beneficioses. I no hi faltaren les tensions, sobretot arran de les repetides anul-lacions papals de l'elecció de bisbe pel capítol i durant els anys de l'administració apostòlica de Pedro de Luna, imposada pel papa al capítol i

\footnotetext{
${ }^{126} \mathrm{ACA}$, Cancelleria, reg. 2202, fols. 172 v. $-173 \mathrm{r}$.

${ }^{127}$ ACA. Cancelleria, reg. 2187, fol. $61 \mathrm{r}$.
} 
a la diòcesi. Crec que els eclesiàstics honorables i cults que formaven la comunitat capitular i els fidels cristians de la diòcesi no mereixien viure aquelles situacions creades per interessos no sempre nobles, intromissions injustes, oblits excessius i, sobretot, per la neutralitat de Pere III envers els papes de Roma i Avinyó, el descarat nepotisme de Maria de Luna i les conseqüències del cisma de l'Església. Afrontant tots els inconvenients esmentats i superant tota mena d'obstacles, el capítol catedralici reeixí en la tasca constructora de la seu gòtica, com ho féu en el foment de la litúrgia i de la devoció popular a la Mare de Déu de la Cinta, reeixint també molt notablement en la preservació i difusió de la cultura teològica, bíblica, jurídica, filosòfica, mèdica i literària des del focus de l'escola catedralícia i del seu scriptorium.

\title{
FONTS I BIBLIOGRAFIA
}

\section{Fonts inèdites}

\author{
A. Arxiu de la Corona d'Aragó (Barcelona) \\ 1. Cancelleria Reial. \\ Registres de Cancelleria.
}

Els registres consultats abracen els regnats de Pere el Cerimoniós, Joan I i Martí l'Humà. Són els següents:

Pere el Cerimoniós: registres 805, 806, 807, 808, 810, 812, 816, 832, $1070,1085,1138,1190,1194,1232,1233,1236,1242,1254,1265,1266,1268$, 1269, 1271, 1274, 1275, 1281, 1458, 1553.

Sibil la de Fortià (quarta esposa de Pere el Cerimoniós): regs. 1587, 1588. Lloctinença de l'infant Joan: regs. 1656, 1727, 1745, 1747.

Joan I: regs. 1833, 1875, 1881, 1885, 1886, 1928, 1960.

Lloctinença de l'infant Martí: reg. 2068.

Martí I: regs. 2151, 2152, 2171, 2172, 2182, 2183, 2187, 2202, 2291, 2292.

Maria de Luna (primera esposa de Martí I): regs. 2336, 2337, 2348.

2. Reial Patrimoni.

Subsecció Mestre Racional: vol. 1625. 
B. Arxiu Capitular de Tortosa (Tortosa)

Breviari de la Catedral. Venècia, 1507.

\section{Bibliografia}

Almuni Balada (Victòria), L'obra de la Seu de Tortosa (1345-1441), Tortosa, Cooperativa Gràfica Dertosense, 1991.

BAYERRI BERTOMEU (Enrique), Historia de Tortosa y su comarca, vols. VVIII, Tortosa, Imprenta Algueró y Baiges, 1948-1960.

Eubel (C.), Hierarchia catholica medii aevi, Munster, 1898-1901.

Herrero García (Miguel), El reloj en la vida española, Madrid, Biblioteca literaria del relojero, 1955.

JosÉ I PITARCH (Antoni), Imatges de Sant Pere i de Maria Magdalena del retaule Major de la Seu de Tortosa, a "Millenum", Barcelona, 1989, p. 272.

Jover Flix (Mariano), Tortosa. Testimonio histórico-gráfico, Tortosa, Cooperativa Gráfica Dertosense, 1973.

- La Santa Cinta. VIII Centenario. 1178-1978, Tortosa, Cooperativa Gráfica Dertosense, 1978.

MANOTE (Rosa Maria), entrada Roca, Bernat, a Gran Enciclopèdia Catalana, 12, Barcelona, 1978.

MONTAÑÉs FONTENLA (Luis), Capítulos de la relojería española, Biblioteca literaria del relojero, Madrid, 1954.

O'Callaghan (Ramón), Anales de Tortosa e historia de la Santa Cinta, Tortosa, Imprenta Católica de Gabriel Llasat, 1886.

PASTOR (J.), El reloj público, a "La Zuda", Tortosa, 31 juliol 1917.

Risco (Manuel), España sagrada, vol. 42, Madrid, Imprenta de la Vda. de don Joaquín Ibarra, 1801 .

VILLANUEVA Y ASTENGO (Joaquín Lorenzo), Viage literario a las iglesias de España, vol. V, Madrid, Imprenta Real, 1806. 


\section{APÈNDIX DOCUMENTAL}

1380, gener, 4 .

Pere III exigeix al capitol de canonges de la seu de Tortosa i a Joan de Castre, tresorer, encarregat de recollir els drets pertanyents a la cambra apostòlica, que retornin al rellotger del rellotge de la seu, Joan de Tornay, els béns mobles, diners i pertinences que té guardats dins la casa que el capitol li havia cedit gratuitament perquè hi visqués $i$ hi fabriqués el réllorge. Joan de Castre, ocupant la casa esmentada, s'apropia dels béns del rèllotger per cobrar-se'n el lloguer contra el que s'havia convingut. I mana que, si s'ha de pagar algun lloguer, la meitat la satisfaci el capitol i l'altra meitat la tregui dels fons de la cambra apostòlica.

ACA, Cancelleria, reg. 806 , fol. 11 r.v.

Petrus, et cetera, dilectis nostris Capitulo et Johanni de Castre, canonico et thesaurario ecclesie dertusensis, deputato ad colligendum et recipiendum iura camere apostolice pertinentia in diocesi dertusensi, salutem et gratiam. Johannes de Tornay, magister aloretgiorum, nobis exposuit reverenter quod, licet ipse nullum loguerium solvere teneretur de seu pro quadam domo, quam ante fabricationem alorotgii, quod in dicta ecclesia construxit, consignarunt ei Episcopus tunc et capitulum ecclesie memorate ut in ea dictum alorotgium operaretur et foveret habitationem suam donec alorotgium ipsum perfectum esset, cum ita conventum fuisset inter eos, vos tamen, dictus Johannes, accipiendo ad manus vestras nomine dicte camere apostolice domum predictam velut dicte camere pertinentem, cepistis utique et penes vos detinetis certam peccunie summam et omnia bona mobilia que dictus exponens habebat in domo ipsa pro eo quia asseritis eum vobis seu dicte camere teneri in loguerio dicte domus. Quocirca, supplicato nobis humiliter super hiis debite provideri, quia sumus veridice informati narrata desuper subsistere veritate, sic huiusmodi serie duximus providendum, videlicet, quod medietas dicti loguerii seu eius quod ex eo debeatur per vos, dictum capitulum, et alia medietas de bonis et iuribus dicte camere persolvatur. Unde volumus et vobis, dicto Johanni, 
tamquam collectori predicto, dicimus et mandamus expresse quatenus, dicto capitulo predictam medietatem modo vobis solvente, quam et per ipsum precepimus, visis presentibus, vobis solvi peccuniam et omnia alia bona predicta capta per vos dicto supplicanti, ut predicitur, intus domum iam dictam occasione predicta restituatis et deliberetis eidem confestim vel cui voluerit loco sui infra tres dies a presentatione huiusmodi computandos, omni dilatione et exceptione remotis. Alioquin, fideli portario nostro Johanni Garcies committimus et expresse mandamus quod memoratum capitulum et vos ad premissa facienda et complenda prout distinguntur superius et ad solvendum etiam de bonis eorum et vestris propriis dicto supplicanti omnes expensas factas et fiendas legitime per eum premissorum occasione una cum salario dicti portarii, quod taxamus ad septem solidos barchinonenses pro qualibet die qua circa hec oportuerit eum vacare, cogat fortiter et districte remediis quibus decet. Nos enim super predictis et dependentibus ac emergentibus ex eisdem committimus dicto portario plenarie vices nostras, iniungentes firmiter et expresse, sub pena centum morabetinorum auri, quibuscumque officialibus nostris ad quos spectet quod super predictis assistant eidem portario consilio, auxilio et favore quotiens et prout inde per eum fuerint requisiti.

Datum Barchinone, quarta die januarii, anno a nativitate Domini $\mathrm{M}^{\circ} \mathrm{CCC}^{\circ}$ LXXXo.

Luppus, cancellarius regius.

Bartholomeus Sirvent ex petitione facta per cancellarium regium.

Probata.

1388, gener, 31 .

El rei Joan I demana a Bernat Roca, mestre de la seu de Barcelona, que vagi a Tortosa en companyia d'altres mestres d'obra, fent dret camí i deixant tota altra obra en construcció, perquè el necessiten els prohoms de la ciutat per veure si és possible treure aigua del riu Ebre $i$ construir una sèquia per regar una partida del terme municipal.

ACA, Cancelleria, reg. 1833, fol. 10 r.v.

En Joan, et cetera. Al feel nostre en Bernat Roca, maestre de la seu de Barchinona, salut e gràcia. Com los prohòmens de Tortosa hajen mester vós e altres maestres semblants per livellar, veure e consellar si és possible de traure e haver per cèquia aygua del flum d'Ebre per regar alguna partida del terme d'aquella ciutat. E lo bé e profit de nostres sotsmeses reputem ésser nostre. Per ço us deim e 
expressament vos manam que dimecres primer vinent partiscats d'ací de Barchinona e anets dret camí a la dita ciutat de Tortosa ab en Gabriel Segarra, lo qual és ací vengut per aquesta raó, e livellets, vejats e consellets si del dit flum d'Ebre se porà traure aygua per cèquia durable segons damunt és dit, totes altres obres, per vós començades, lexades. E en açò escusa o dilació alguna no metats. Corn los dits prohòmens sien aparellats de satisfer vos per vostres treballs. Certificants vos que d'açò'ns farets plăer e del contrari nos faríets desplaer.

Dada en Barchinona, lo derrer dia de janer. En l'any de la nativitat de Nostre Senyor mil trescents vuytanta vuyt.

Francesc Ça Costa.

Dominus rex mandavit mihi, Berengario Segarra.

Probata.

1383, febrer, 11 .

Pere el Cerimoniós escriu al prior i capitol de la seu de Tortosa demanant-los que, després d'haver-se'n anat de l'obra de la seu el mestre que hi treballava, rebin com a mestre Pere Ça Fàbrega, mestre d'obres de la ciutat, que ja havia estat dirigint la construcció de la nova catedral. Aquesta és també la voluntat dels ciutadans i representants municipals, això és, que el mestre de la seu sigui el mateix de la ciutat, assegurant-se aixi la presència del mestre a l'obra. El capitol volia que la cosa fos al revés, que el mestre de la seu ho fos de la ciutat. Arran d'aquest afer s'han originat unes divisions entre el capitol $i$ la ciutat, que el monarca vol acabar amb la seva intervenció.

ACA, Cancelleria, reg. 1281 , fol. 102 r.

Lo Rey.

Prior e capítol, sabut havem de cert que en Pere Ça Fàbrega solia ésser maestre en vostra seu. E aprés és se seguit que un altre que'n hi havíets mes se'n és anat. E per tal com entre vosaltres e la ciutat ha hauda alguna divisió sobre aquest fet en ço que vosaltres volíets que lo maestre vostre fos maestre de la ciutat. E los ciutadans han volgut que el dit Pere Ça Fàbrega sia estat maestre lur, nós havem pensat e volem que el dit Pere Ça Fàbrega cobre lo maestrat vostre e sia maestre de la seu e de la ciutat. E ab tant serà tolta la dita divisió. Per què us pregam e manam que el dit Pere Ça Fàbrega reebats en maestre de la seu e li responats dels drets que havia acostumats a reebre. Certificants vos que d'açò'ns farets plaer e servey, lo 
qual molt vos grahirem. E darets loch a concòrdia entre vosaltres e la dita ciutat. E gardats vos que no ho façats axí com fets de moltes coses de què us pregam e vosaltres non fets res, que pensar podets que no les vos pendrem totes en paciència. Ans si'l contrari fahíets, ço que no creem, vos darem a conèixer que ens en fets desplaer e desservey.

Dada en Tortosa, sots nostre segell secret, a XI dies de febrer del any M CCC LXXXIII. Rex Petrus.

Michael de Bordello, mandato regio facto per Bernardum de Fortiano, militem, consiliarium et camerlengum. El fuit mihi tradita in hac forma.

Probata.

1383, abril, 22.

Pere el Cerimoniós, assabentat que Joan de Mayni, mestre de la seu de Tortosa, vol abandonar la ciutat abans d'acabar la capella de sant Pere, que era a punt d'acabar-se, li mana baix pena de cent morabatins d'or que no deixi l'obra inacabada, no en prengui cap altra de nova ni marxi de la ciutat fins que la capella sigui acabada. Després podrà sortir de Tortosa només amb llicència dels procuradors de les obres de la seu i pel temps que aquests autoritzin.

ACA, Cancelleria, reg. 832, fols. 177 v. -178 r.

En Pere, et cetera. Al feel nostre en Johan de Mayni, obrer de la Seu de Tortosa, salut e gràcia. Com haiam entès que vos volets partir de la dita ciutat no acabada la capella de Sent Pere, la qual està en acabament, e nos haiam affecció que la dita capella fos complidament acabada, manam vos espressament, sots pena de cent morabatins d'or de vostres béns sens tota remissió e gràcia havedors, que de la dita ciutat no partiscats, ne altra obra façats ne prengats tro la obra de la dita capella sia, segons que és dit, acabada. E ladonchs e no abans, ab licència dels procuradors de la obra de la dita Seu, puxats a cert temps fora la dita ciutat anar e estar segons que ab ells d'açò vos convindrets, no contrestant promissió qualsevol a altres per vos feta, la qual nos en favor de les dites obres suspenem e volem en perjudici d'aquelles no haver loch. Dada en Tortosa, a XXII dies d'abril. En l'any de la nativitat de nostre Senyor M CCC LXXXIII. Rex Petrus.

Dominus Rex mandavit mihi, Bartholomeo Sirvent.

Probata. 
1383, abril, 10 .

Pere el Cerimoniós mana al mestre racional, Bernat Calopa, collidor i administrador dels béns pertanyents a la cambra apostòlica, que doni d'aquests béns vint florins d'or d'Aragó a fra Joan de Fornells, arquebisbe de Torres, pels seus serveis pontificals i benedicció dels olis sants a la seu de Tortosa el dijous sant.

ACA, Cancelleria, reg. 1458, fol. 117 r.

En Pere, al feel del ofici de mestre racional de casa nostra en Bernat Calopa, reebedor e administrador general dels béns o drets pertanyents a la cambra apostolical, salut e gràcia. Com lo reverend pare en Crist frare Johan, arcabisbe de Torres, benehís en lo dijous sant del any present la Crisma en la seu de Tortosa per ço com noy ha prelat e per raó de sos treballs li haiam manat dar vint florins d'or d'Aragó, per ço us dehim e manam de certa sciència e espressament que de qualsevol moneda que és o serà vers vos per raó dels dits béns e drets apostolicals paguets al dit arcabisbe o a qui ell volrà los dits XX florins cobrant d'ell la present ab àpoca de paga. Car nos ab aquesta matexa vos absolem quant a açò dels sagrament e homenatge per vós fets de no pagar res de la dita moneda sinó segons forma dels capítols per nós sobre açò derrerament fets, com no vullam aquells sagrament e homenatge ésser esteses als dits XX florins. E nós ab aquesta mateixa manam al mestre racional de la nostra cort o a altre de vós compte oydor que, vós restituent li la present e la dita àpoca, los dits XX florins vos prena en compte $\mathrm{e}$ dubte alcú no us hi faça.

Dada en Tortosa, a X dies d' abril, en l'any de la nativitat de Nostre Senyor M CCC LXXXIII. Rex Petrus.

Dominus rex mandavit mihi, Berengario Vallossera.

Probata.

1382, abril, 1.

L'infant Joan exigeix al prior, ardiaca i capitol de la seu de Tortosa el pagament, en un termini de sis dies, dels cinquanta florins d'or d'Aragó promesos al bisbe de Konavlje (Dalmàcia), fra Francesc Janer, cridat a Tortosa pels canonges per fer-hi serveis pontificals. El bisbe hi va des de Perpinyà amb 
gran esforç $i$ afany, però quan ja és a Tortosa li diuen que no el necessitaven $i$ li paguen solament vint-i-cinc florins, prometent-li que els altres vint-i-cinc, que el bisbe no es cansava de reclamar, els hi pagarien més endavant. L'infant recrimina als canonges l'actitud $i$ el tracte que fan al bisbe i la demora del pagament de la meitat dels florins promesos.

ACA, Cancelleria, reg. 1727, fol. 150 r.

Infans Johannes, fidelibus nostris priori, archidiacono et capitulo Sedis Dertusensis, salutem et gratiam. Per venerabilem in Christo patrem, fratrem Franciscum, Cuniavensem episcopum, extitit nobis reverenter expositum cum querela quod, cum vos, pro ministrandis ibidem pontificalibus sacramentis, pridem de villa Perpiniani feceritis ipsum venerabilem episcopum apud dictam Sedem Dertusensem venire, et non de ipso verecundantes qui ad magnam instantiam venit, cum inibi fuerit, asseruistis pro eisdem eum non habere necessarium, ob quod eidem quinquaginta florenos auri pro expensis per ipsum hac de causa sustentis elargiri promissistis in manibus suis per diversos dicti capituli. Ex quibus, viginti quinque florenos eidem tribuistis, promittentes alios infra mensem julii proxime lapsum solvere, et eidem non compensato, cum sit prelatus et vos religiosi, suo damno, verecundia et labore. Et licet residuos viginti quinque florenos pluries cum instantia tam per litteras suas quam aliter vobis petierit, attamen vos dictam residuam florenorum quantitatem eidem persolvere recusastis et recusatis etiam de presenti in evidens ipsius episcopi dampnum et perjuditium manifestum. Unde, supplicato nobis humiliter sibi super hiis decens remedium impertiri, vobis et cuilibet vestrum dicimus et expresse mandamus quatenus infra sex dies a presentatione presentium vobis facta in antea continue numerandos prefatam peccunie quantitatem eidem, prout tenemini et debetis, exsolvatis seu exsolvi protinus faciatis, malitiis et diffugiis omnibus penitus semotis vel ipsa sexta die, que, si feriata fuerit, sequenti non feriata, per vos vel vestrum idoneum responsalem coram nobis seu in nostri cancellaria ubicumque fuerimus compareatis parati proponere iustas causas propter quas ad predicta non teneamini, aliter, lapsis dictis sex diebus, si predicta, quod nullatenus oppinamur, facere neglexeritis, scire vos volumus quod nos taliter pro hiis contra vos procedemus quod nostris non adhesisse mandatis vos merito penitebit.

Datum Terracone, prima die aprilis, anno a nativitate Domini $\mathrm{M}^{\circ} \mathrm{CCC}^{\mathrm{o}}$ $\mathrm{LXXX}^{\circ}$ secundo. Primogenitus.

Dominus dux mandavit mihi, Galcerando de Ortigis, et fuit mihi tradita in hac forma.

Probata. 
1403, gener, 19 .

El rei Martí I s'adreça al papa Benet XIII comunicant-li que l'ardiaca major de la seu de Tortosa, mogut per l'enveja i la malvolença que té a Jaan Siurana, prior major, elegit pel capitol per a bisbe, ha escrit una carta calumniosa contra ell i contra la majestat reial. Per tractar d'aquest greu afer envia a la cort d'Avinyó, a entrevistar-se amb el papa, Jaume de Prades, parent del rei i conestable d'Aragó.

ACA, Cancelleria, reg. 2291, fol. 165 r.v.

Sanctissime et beatissime pater, super aliquibus interesse nostrum tangentibus de et super quadam littera per archidiaconum maiorem Ecclesie Dertusensis malitiose, ut dicitur, contra priorem maiorem dicte ecclesie fabricata post electionem seu postulationem dudum per capitulum dicte ecclesie factam de persona prioris iamdicti in dicte ecclesie presulem et pastorem, informạvimus de facti veritate ac intentione nostra literatorie per extensum egregium virum Jacobum de Prades, conestabulum Aragonum, consanguineum nostrum percarum. Vestre igitur Sanctitati humiliter supplicamus quatenus relatibus consanguinei nostri predicti dignetur Vestra Beatitudo Sanctissima super istis fidem credulitatis indubie adhibere ac si ea per nos Vestre Sanctitati proprio organo dicerentur. Almam personam vestram regimini universalis ecclesie perlectam conservare dignetur Altissimus per tempora longiora.

Datum Valentie, XIX die januarii, anno a nativitate Domini Millesimo CCCCo tertio. Rex Martinus.

Gabriel Mascaroni, mandato domini regis facto per Petrum de Turrillis, militem, consiliarium.

Probata.

1403, gener, 19.

El rei Martí I escriu al seu cosí, Jaume de Prades, referint-li l'afer de la malvolença de l'ardiaca major de Tortosa, Joan Amargós, envers el prior major, Joan Siurana, arran de l'elecció capitular d'aquest per a bisbe. Li fa saber que hi ha una carta manuscrita de la pròpia mà de l'ardiaca contenint 
gravissima calúmnia de suborn que afecta el prior del capitol i també la dignitat reial, per la qual cosa l'envia a Avinyó a tractar amb Benet XIII $d$ 'aquest afer com a ambaixador $i$ confident reial.

ACA, Cancelleria, reg. 2291, fol. 165 r.

\section{Lo Rey d'Aragó.}

Molt car cosí. Aprés la transportació feta per lo Sant Pare del venerable en Crist N'Huch, per la divinal providència olim bisbe de Tortosa, en lo bisbat de València, per lo capítol de la dita esgleya de Tortosa fon elegit o postulat en bisbe de aquella lo prior maior de aquella esgleya. Aprés de la qual elecció o postulació, per lo artiacha maior de la dita esgleya, per enveia o malvolença del dit prior elet o postulat, fon atrobada una letra scripta de mà del dit artiacha, axí com ell ha atorgat en ple capítol, segons se diu, continent entres les altres coses, que lo dit prior lavors elet o postulat, volent haver lo dit bisbat a mà nostra, havia promeses a nós grans quantitats o millers de florins, e que de fet nós li donàssem la possessió del dit bisbat, la qual cosa fretura de tota veritat com per lo dit prior o altre en nom o per part sua may no sia stada feta a nós tal o alguna altra proferta ne nós hi donarem loch algú. Perquè sentints nós d'açò per nostra honor axí com se pertany e per descàrrech e scusació del dit prior, vờs pregam tant com podem e us encarregam que per virtut de la creença, la qual sobre aquest fet comanam a vós ab nostra letra, que trametem al Sant Pare, li expliquets per part nostra totes les dites coses e de nostra part suppliquets a la Sua Santedat per nostra honor e scusació del dit prior, segons dit és, que a tals coses no vulla donar creença alguna com nós no haiam acostumat per diners o remuneració supplicar o scriure en favor d'algú. mil CCCC III.

Dada en València, sots nostre segell secret, a XVIIII dies de jener del any

Gabriel Mascaroni, mandato domini regis facto per Petrum Turrillis, militem et consiliarium.

Probata.

1399, maig, 8 .

La reina Maria de Luna, havent quedat vacant el bisbat de Tortosa pel trasllat a la seu de València del bisbe Hug de Llupià, recomana al capítol tortosí per a bisbe de Tortosa, manifestant-los que aquesta és també la voluntat del rei Martí, el seu cosi Pedro de Luna, del qual elogia les facultats humanes $i$ 
espirituals alhora que recorda el parentiu que té amb ella i amb el papa Benet XIII, a qui ha escrit perquè el fes bisbe de la diòcesi.

ACA, Cancelleria, reg. 2337 , fols. 42 v. -43 r.

Regina Aragonum.

Videntes, experientia edocente, quod uniuscuiusque ecclesie, maxime cathedralis, conservatio et augmentum a suo principaliter dependet preside et pastore, in desideriis propterea et utique respectu debiti parentele quo nobis est iunctus vir nobilis Petrus de Luna, decretorum professor, domini Summi Pontificis nepos, gerimus mentis nostre quod ex quo suum in omnibus est sortita effectum translatio venerabilis patris Hugonis, olim dertusensis episcopi, ad ecclesiam valentinam, preficeretur in ecclesie dertusensis antistitem Petrus ipse, in quem nobilitas generis, amicorum potentia, scientie profunditas, vite et morum honestas, industria circumspecta et alie quoque dotes virtutum uberrime fluere dinoscuntur. Et licet fidentius prestolemur sibi de ipsa ecclesia per dictum dominum Summum Pontificem, cui super hoc hoc scripsimus provideri, quare tamen omnia cupimus ad huiusmodi provisionem concurrere, que illam deceant, solident et honestent, vos tamen et quemlibet vestrum cordialiter deprecamur quatenus, premissorum intuitu et domini pape et nostri respectu honoris, velitis Petrum eundem, de quo dicte vestre ecclesie firma potestis, dante Domino, expectare fiducia optime provideri, eligere in vestrum et ipsius ecclesie presulem et pastorem. Scituri quod nobis ex singulare impendetis obsequium, pro quo semper ecclesiam ipsam ac vos omnes et singulos in vestris habebimus opportunitatibus propensius recommissos ut cognoscetis a fructibus suo casu.

Datum Cesarauguste, die octava mensis madii, anno a nativitate Domini $\mathrm{M}^{\circ}$ $\mathrm{CCC}^{\circ} \mathrm{XC}^{0}$ nono. La Reyna.

Domina regina mandavit mihi, Bartholomeo Sirvent.

Probata.

1399, maig, 30 .

Maria de Luna expressa al prior i capitol de la seu de Tortosa el seu disgust i la seva impaciència perquè no havien estat escoltats ni atesos els precs del rei Martí i seus a favor de l'elecció i acceptació de Pedro de Luna per a bisbe de la diòcesi, fet que la reina atribueix a l'egoisme, cupiditat i inducció del prior major i dels canonges que havien elegit aquest per a bisbe seguint les ordinacions capitulars antigues. 
La Reyna.

Prior e capítol, sus ara havem sabut que encara no són exausits los prechs no poch affectuosos del senyor rey, marit e senyor nostre molt car, e nostres, que us faem d'aquests jorns per nostres letres de e per la elecció de nostre car cosí don Pedro de Luna, doctor en decrets, canonge e pebordre de València, en bisbe e pastor vostre e de la vostra esgleya de Tortosa, ans se diu que alcuns de vosaltres, no attenents la gran sciència e virtuts moltes ne les altres qualitats concorrents en la persona del dit don Pedro, ço és lo gran acostament que ha ab lo papa, del qual, segons sabets, és nebot e amat fort tenrrament, lo gran deute de sanch en què és ab nós, la potència de sos parents e amichs e la transcendent affecció quel senyor rey e nós havem a la sua promoció en bisbe dessús dit, la qual evidentment s'espera molt fructuosa e honorabla a la dita esgleya e a vosaltres, ne advertints per consegüent que per les dites raons no podets a adés fer equivalent elecció, mas, deecebuts alcuns per pròpia cupiditat $e$ alcuns per inducció d'altres, havets feta e fets collusió per colligança de e sobre elecció faedora d'altre, de què, si axí és, fort meravellada per les raons dessús dites e car ne pendríets masse gran càrrech e de no poca e assenyalada descomplacència e ingratitud del Sant Pare e del senyor rey, als quals, davant tots altres, atteses maiorment les dites coses, ne devets gratificar $\mathrm{e}$ complaure. Perquè jassia esperem fermament e siam en cert quel papa provehirà, si ia no hi ha provehit, al dit nebot seu de la dita esgleya e, per consegüent, no li fos necessària la elecció dessús dita. Empero, car segons vos havem ia escrit, nostra affecció e plaer és e serà que concórreguen en la sua provissió dessús dita totes coses que aquella soliden e honesten, pregam vos altra vegada, tan cordialment com podem, que, foragitada tota ambició pròpia e tota sinistra suasió squivada, façats la dita elecció canònicament, liberalment e prompta. E farets ço que devets, proseguirets lo bé e honor de la dita esgleya e vostre e complaurets ne singularment al papa y al senyor rey qui estretament vos n'escriu e que lo contrari prendria impacientment e a nós no menys, que per açò haurem la dita esgleya e vosaltres en universal e en particular en recomendació special.

Dada en Saragoça, a XXX dies de maig del any M CCC XC nou. La Reyna.

Domina regina mandavit mihi, Bartholomeo Sirvent.

Probata. 
1399, juny, 20.

La reina Maria de Luna escriu al vicari general del bisbat i al prior $i$ capítol de la seu de Tortosa en resposta a una carta del capítol en la qual els canonges li havien fet saber que no podien consentir a l'elecció ni a l'acceptació de la persona de Pedro de Luna com a bisbe perquè ho impedien les ordinacions antigues del capítol $i$ del bisbat. La reina els demana que s'abstinguin de fer elecció de bisbe.

ACA, Cancelleria, reg. 2337, fol. 55 v.

La Reyna.

Prior, vicari i capítol, pus, vedant la constitució allegada per vosaltres, no pot ésser elegit ne postulat en bisbe d'aqueixa esgleya sinó canonge reglar vestit d'hàbit canonical, e havets dit e affermat per vostra letra responsiva a les nostres e de paraula que us sap fort greu, car, prohibent la dita constitució, no podets complaure a nostra affecció e prechs de la elecció e postulació de nostre car cosí don Pedro de Luna, maiorment per la sua sciència e mèrits virtuosos e del deute de sanch que ha ab nós. E veents que elegir o postular altre no profeteria res com siam certa quel papa, son oncle, provehirà a ell, si ja nol ha provehit, e no a altre de la dita esgleya, pregam vos de cor que de tota elecció o postulació vos vullats, per consideració de les dites coses e honor nostra, abstenir. E farets nos en plaer e servey fort agradable, que molt vos grahirem, segons conexerets en son cas e loc e squivarets ne desgrats que de la dita elecció o postulació poríets leugerament encórrer en seguiríets segons nostra oppinió lo pus espedient a la dita esgleya e a vosaltres mateys.

Dada en Saragoça a XX dies de juny del any M CCC XC IX. La Reyna. Domina regina mandavit mihi, Bartholomeo Sirvent.

Probata.

\section{RÉSUMÉ}

Cet article résume une grande partie de l'abondante documentation relative à la cathédrale, au Chapitre des chanoines et à l'évêché de Tortosa, documentation qui a été trouvée par l'auteur dans les registres de la Chancellerie Royale et dans les fonds du Patrimoine des Archives Royals de Barcelone. Il s'agit d'une documentation datée de la deuxième moitié du XIVème siècle et premières années du XVème, qui vient compléter celle des Archives Capitulaires de la cathédrale de Tortosa. 
Dans la première partie de l'article on y étudie l'activité constructive de la cathédrale gothique, on y fait connaître l'identité de quelques-uns des maitres d'oeuvre et leur comportement pendant l'oeuvre ainsi que leurs rapports envers le Chapitre de la cathédrale et avec d'autres maîtres de l'époque. Cette documentation nous permet de connaittre et de suivre de près les travaux de la cathédrale et les périodes de la plus grande ou de la moindre activité qui se correspond, il paraît que celà en est ainsi, aux differentes situations favoravles ou défavoravles de la vie du Chapitre.

Dans la deuxième partie toute l'attention ést axée sur le Chapitre de la cathédrale, sur les dignités et chanoines qui la formaient, sur les circonstances qu'ils avaient à vivre, sur les ingérences qu'ils devaient affronter et sur les tensions internes duées aux ingérences royales, au peu de considération de la Papauté ou à la neutralité du Roi Pere III (Pierre Troisième) pendant le Schisme d'Occident. La défense que le Chapitre fait de ses droits pendant l'administration apostolique de Pedro de Luna (1399 - 1403) qui leur fut imposée, mérite une analyse détaillée qui se réflète dans l'appendice documentaire.

\section{SUMMARY}

This article compiles a large part of the copious documentation concerning the cathedral, the Chapter of the Augustinian canons and the bishopric of Tortosa, investigated by the author in de registries of the Royal Chancery and the archives of the Royal Property Record Office of Barcelona. These documents, which go from the second half of the XIV century to the beginning of the $\mathrm{XV}$, complete the documentation from the Chapter Archive of the Cathedral of Tortosa.

In the first part the author studies the works undertaken to build the gothic cathedral, identifies some of its masters and their role in the construction, as well as their relations with the Chapter of the Cathedral and other master builders at that time. It is a very close approach to those works and the periods of greater and lesser activity, which apparently reflect the different times undergone by the Chapter.

The second part focuses on the Chapter of the Cathedral and its different dignitaries and canons, its internal matters, the conflicts created by external interference as well as the internal tensions aroused by royal interference, the Pope's lack of interest and the neutrality of King Pere III concerning the Schism of Western Christianity.

The defense by the Chapter of its rights under the administration, imposed on them, of Pedro de Luna (1399-1403) is analysed in detail and results in an appendix of documents. 